\title{
REVIEW OF ALTERNATIVE ENHANCED CHEMICAL CLEANING OPTIONS FOR SRS WASTE TANKS
}

August 2009 


\section{DISCLAIMER}

This work was prepared under an agreement with and funded by the U.S. Government. Neither the U. S. Government or its employees, nor any of its contractors, subcontractors or their employees, makes any express or implied:

1. warranty or assumes any legal liability for the accuracy, completeness, or for the use or results of such use of any information, product, or process disclosed; or

2. representation that such use or results of such use would not infringe privately owned rights; or

3. endorsement or recommendation of any specifically identified commercial product, process, or service.

Any views and opinions of authors expressed in this work do not necessarily state or reflect those of the United States Government, or its contractors, or subcontractors.

This document was prepared in conjunction with work accomplished under Contract No. DE-AC09-08SR22470 with the U.S. Department of Energy.

Printed in the United States of America

Prepared For

U.S. Department of Energy 
Key Words:

Sludge Heel

Acid Cleaning

\title{
Retention: Permanent
}

Key References:

Technical Task Plan: WSRC-RP-2008-00613

SEE: SRNL-L3100-2009-00118

\section{REVIEW OF ALTERNATIVE ENHANCED CHEMICAL CLEANING OPTIONS FOR SRS WASTE TANKS}

\author{
M. S. Hay, SRNL/A\&CPT \\ D. C. Koopman, SRNL/PTP
}

Issue Date: August 2009 


\section{REVIEWS AND APPROVALS}

M. S. Hay, Author, SRNL/A\&CPT

Date

D. C. Koopman, Author, SRNL/PTP

Date

W. D. King, Technical Reviewer, SRNL/A\&CPT

Date

F. M. Pennebaker, Manager SRNL/A\&CPT

Date

S. L. Marra, Manager, SRNL/E\&CPT Research Programs

Date 


\section{TABLE OF CONTENTS}

LIST OF TABLES IV iv

LIST OF ACRONYMS v v

SUMMARY vi vi v

$\begin{array}{ll}1.0 \text { INTRODUCTION } & 1\end{array}$

2.0 BASELINE CHEMICAL CLEANING OF TANK HEELS 3

2.1 ReCENT DeVELOPMENTS WITH OXALIC ACID ClEANING

2.2 OPTIMIZING MECHANICAL CLEANING $\quad 6$

2.3 OPTIMIZING OXALIC ACID USAGE $\quad 7$

2.4 SLUDGE HEEl NEUTRALIZATION WITH MinERAL ACIDS

2.5 IMPACTS OF OXALATE ON THE DOWNSTREAM PROCESSES 9

3.0 OXALIC ACID DESTRUCTION TECHNOLOGIES 10

3.1 CHEMICAL OXIDATION OF OXALIC ACID 10

3.2 ELECTROCHEMICAL OXIDATION OF OXALIC ACID 12

3.3 ULTRA VIOLET RADIATION FOR OXIDATION OF OXALIC ACID 12

3.4 ADVANCED OXIDATION PROCESSES 12

3.5 OTHER OXIDATION PROCESSES 13

4.0 ALTERNATIVE CHEMICAL CLEANING TECHNOLOGIES 14

4.1 OTHER ACIDS 14

4.1.1 Sinkov Review of Various Treatments

4.1.2 Chen Decontamination Review 17

4.1.3 Shields Chemical Cleaning Review 18

4.1.4 Wang-Stone Mn Dissolution Paper 18

4.1.5 Powell Paper on U(VI) and Boehmite 18

4.1.6 Al-Hobaib Paper on Ra Desorption, Mn, and Fe Reductive Dissolution 19

4.1.7 Enda et al. Patent (Formic acid-Oxalic acid)

4.2 Caustic Chemical Cleaning 19

4.3 ORGANIC COMPLEXANTS 20

4.4 INDUSTRIAL PROCESSES $\quad 21$

$\begin{array}{ll}\text { 5.0 DISCUSSION AND CONCLUSIONS } & 23\end{array}$

5.1 GENERAL DiSCUSSION ON THE LiTERATURE REVIEW 23

5.2 RESULTS OF THE TECHNOLOGY EVALUATION 24

5.3 RECOMMENDATIONS FOR FUTURE WORK 26

$\begin{array}{ll}\text { 6.0 REFERENCES } & 27\end{array}$ 


\section{LIST OF TABLES}

Table 2-1. Estimated Percentage of Key Elements Dissolved from the TANK 5F Sludge ................3

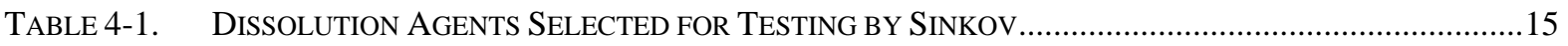




\section{LIST OF ACRONYMS}

\begin{tabular}{ll} 
AECC & Alternative Enhanced Chemical Cleaning \\
AOP & Advanced Oxidation Processes \\
Can-Decon & CANDU Decontamination \\
CITROX & Citric Oxalic with Exchange \\
CORD-UV & Chemical Oxidation Reduction Decontamination-UV \\
CPC & Chemical Process Cell \\
DfD & Decontamination for Decommissioning \\
DfDx & Decontamination for Decommissioning-Advanced \\
DOE & Department of Energy \\
DWPF & Defense Waste Processing Facility \\
EDTA & Ethylenediaminetetraacetic Acid \\
HAF & Hydroxyacetic-Formic Acid \\
HEDPA & 1-Hydroxyethane-1,1-Diphosphonic Acid \\
HLW & High-Level Waste \\
HM & H-Area Modified \\
LTAD & Low Temperature Aluminum Dissolution \\
LOMI & Low Oxidation Metal Ion \\
LWO & Liquid Waste Operations \\
PUREX & Plutonium Uranium Reduction Extraction \\
SWPF & Salt Waste Processing Facility \\
SRAT & Sludge Receipt and Adjustment Tank \\
SRNL & Savannah River National Laboratory \\
SRS & Savannah River Site \\
TEA & Triethanolamine \\
TTQAP & Task Technical and Quality Assurance Plan \\
UV & Ultra Violet Radiation \\
& \\
\hline
\end{tabular}




\section{SUMMARY}

A literature review was conducted to support the Task Technical and Quality Assurance Plan for Alternative Enhanced Chemical Cleaning (AECC) for sludge heel removal funded as part of the EM-21 Engineering and Technology program. The goal was to identify potential technologies or enhancements to the baseline oxalic acid cleaning process for chemically dissolving or mobilizing Savannah River Site (SRS) sludge heels. The issues with the potentially large volume of oxalate solids generated from the baseline process have driven an effort to find an improved or enhanced chemical cleaning technology for the tank heels. This literature review builds on a previous review conducted in 2003. A team was charged with evaluating the information in these reviews and developing recommendations of alternative technologies to pursue.

The new information in this report supports the conclusion of the previous review that oxalic acid remains the chemical cleaning agent of choice for dissolving the metal oxides and hydroxides found in sludge heels in carbon steel tanks. The potential negative impact of large volumes of sodium oxalate on downstream processes indicates that the amount of oxalic acid used for chemical cleaning needs to be minimized as much as possible or the oxalic acid must be destroyed prior to $\mathrm{pH}$ adjustment in the receipt tank. The most straightforward way of minimizing the volume of oxalic acid needed for chemical cleaning is through more effective mechanical cleaning. Using a mineral acid to adjust the $\mathrm{pH}$ of the sludge prior to adding oxalic acid may also help to minimize the volume of oxalic acid used in chemical cleaning. If minimization of oxalic acid proves insufficient in reducing the volume of oxalate salts, several methods were found that could be used for oxalic acid destruction.

For some waste tank heels, another acid or even caustic treatment (or pretreatment) might be more appropriate than the baseline oxalic acid cleaning process. Caustic treatment of high aluminum sludge heels may be appropriate as a means of reducing oxalic acid usage.

Reagents other than oxalic acid may also be needed for removing actinide elements from the tank heels.

A systems' engineering evaluation (SEE) was performed on the various alternative chemical cleaning reagents and organic oxidation technologies discussed in the literature review. The objective of the evaluation was to develop a short list of chemical cleaning reagents and oxalic acid destruction methods that should be the focus of further research and development. The results of the SEE found that eight of the thirteen organic oxidation technologies scored relatively close together. Six of the chemical cleaning reagents were also recommended for further investigation.

Based on the results of the SEE and plan set out in the TTQAP the following broad areas are recommended for future study as part of the AECC task.

- Basic Chemistry of Sludge Dissolution in Oxalic Acid: A better understanding of the variables effecting dissolution of sludge species is needed to efficiently remove sludge heels while minimizing the use of oxalic acid or other chemical reagents. Tests should 
investigate the effects of $\mathrm{pH}$, acid concentration, phase ratios, temperature, and kinetics of the dissolution reactions of sludge components with oxalic acid, mineral acids, and combinations of oxalic/mineral acids. Real waste sludge samples should be characterized to obtain additional data on the mineral phases present in sludge heels.

- Simulant Development Program: Current sludge simulants developed by other programs for use in waste processing tests, while compositionally similar to real sludge waste, generally have more hydrated forms of the major metal phases and dissolve more easily in acids. Better simulants containing the mineral phases identified by real waste characterization should be developed to test chemical cleaning methods.

- Oxalic Acid Oxidation Technologies: The two Mn based oxidation methods that scored highly in the SEE should be studied to evaluate long term potential. One of the AOP's $\left(\mathrm{UV} / \mathrm{O}_{3} /\right.$ Solids Separator) is currently being implemented by the SRS liquid waste organization for use in tank heel chemical cleaning.

- Corrosion Issues: A program will be needed to address potential corrosion issues from the use of low molarity mineral acids and mixtures of oxalic/mineral acids in the waste tanks for short durations. The addition of corrosion inhibitors to the acids to reduce corrosion rates should be investigated. 


\subsection{INTRODUCTION}

The Savannah River Site has the responsibility of closing the million gallon storage tanks in the $\mathrm{F}$ and $\mathrm{H}$ tank farms. The tank contents will be processed in the Defense Waste Processing Facility (DWPF) and the Salt Waste Processing Facility (SWPF). The SWPF will separate the radionuclides from concentrated salt solutions to create a low activity waste stream as feed to the Saltstone Processing Facility. The radionuclides separated from the salt waste in the SWPF will be combined with the waste tank sludge and processed in the DWPF into a stable borosilicate glass waste form for long-term storage. The first step in closing a waste tank involves bulk waste removal.

Bulk waste removal uses mechanical cleaning to remove the sludge waste from the tank. Agitation pumps mix the sludge solids into the liquid phase allowing the solids to be transported from the tank. Mechanical cleaning of sludge solids using agitation pumps reaches a point of diminishing returns as the volume of sludge solids remaining in the tank becomes low. The presence of large cooling coil networks inside the waste tanks complicates the implementation of other mechanical cleaning technologies. The cooling coils restrict access to regions of the tank and inhibit mixing inside the tank. Mounds of solid-rich sludge remain on the floor of the tank after bulk waste removal. The equivalent depth of residual sludge heel, assuming that the mounds are spread out uniformly across the tank bottom, is thought to be in the range of 1-2 inches ( 3000 to 6000 gal). Compositions of the individual sludge mounds vary from tank to tank due to the two primary processes that produced the sludge, the PUREX and HM processes for enriching and separating uranium and plutonium. Following bulk waste removal, additional tank cleaning technologies will be implemented to remove the small volume of residual waste and prepare the tank for closure.

The baseline technology for chemical cleaning of waste tanks at SRS involves treatment of the tank heels with an $8 \mathrm{wt} \%$ oxalic acid solution at ambient conditions. Oxalic acid cleaning became the baseline technology based on a large body of data obtained through testing with actual and simulated sludge samples. Oxalic acid exhibits relatively low corrosivity to carbon steel versus other common acids and can act as a complexant and reducing agent. These properties make oxalic acid the cleaning agent of choice for removal of rust and other metal oxidation deposits in industrial settings. With iron oxides and hydroxides being a major component of High-Level Waste (HLW) sludge, the application of oxalic acid to clean sludge residue from waste tanks is an appropriate choice.

However, the spent oxalic acid solutions from tank cleaning operations will be transferred to another tank and $\mathrm{pH}$ adjusted, forming large volumes of sodium oxalate precipitates. Material balance calculations indicate this cleaning option may produce quantities of sodium oxalate and saturated oxalate solutions that have the potential to cause processing issues for the SRS tank farms, DWPF, and SWPF. ${ }^{1}$ As a result, the SRS Liquid Waste Operations has proposed a new process for chemical cleaning the incorporates an oxalate destruction step.

The potential issues with the large volume of oxalate solids have driven an effort to find an improved or Alternative Enhanced Chemical Cleaning (AECC) technology for the tank heels. A Department of Energy (DOE) Office of Engineering \& Technology-Waste Processing 
(EM-21) task was funded in fiscal year 2008 to address this complex-wide problem, and a Task Technical and Quality Assurance Plan (TTQAP) was issued covering general issues at the Savannah River National Laboratory (SRNL). ${ }^{2}$ The TTQAP identified the need for a literature review as a first step in the evaluation of alternative technologies. This review complements a previous review of chemical cleaning methods. ${ }^{3}$ 


\subsection{BASELINE CHEMICAL CLEANING OF TANK HEELS}

\subsection{RECENT DEVELOPMENTS WITH OXALIC ACID CLEANING}

Oxalic acid cleaning, the baseline tank cleaning technology at SRS, has been used to clean two waste tanks in the past, Tanks $16 \mathrm{H}$ and $24 \mathrm{H}$. The technology worked well for removing the residual sludge waste in Tank $16 \mathrm{H}^{4}$, but was less effective on the zeolite material in Tank $24 \mathrm{H} .{ }^{5}$ Iron, aluminum, uranium, and manganese dominate the composition of the sludge heel solids as a mixture of hydroxides, oxides, and hydrous oxides. The few x-ray diffraction studies conducted on SRS sludge samples indicate hematite and magnetite as the primary crystalline iron phases and boehmite and gibbsite as the predominant aluminum phases present in the sludge. Oxalic acid can dissolve many of the primary sludge species, since it can act as an acid, a complexant, and a reducing agent. A previous review of tank cleaning methodologies summarizes the cleaning of Tank $16 \mathrm{H}$ and $24 \mathrm{H}$ with oxalic acid. ${ }^{3}$ The initial results of recent oxalic acid cleaning in Tanks $5 \mathrm{~F}$ and $6 \mathrm{~F}$ will be discussed below along with other recent information.

Prior to the start of chemical cleaning operations in Tank 5F, a heel sample was obtained for characterization and testing. ${ }^{6}$ The testing with the Tank $5 \mathrm{~F}$ heel sample examined sludge dissolution from a single contact with $8 \mathrm{wt} \%$ oxalic acid at $50{ }^{\circ} \mathrm{C}$ for a duration of one week. The 20:1 volume of oxalic acid to sludge volume dissolved a large portion of the sludge. Table 2-1 shows the results of the dissolution of major components of the sludge during the test. A second test conducted at $75{ }^{\circ} \mathrm{C}$ showed only marginally higher dissolution of the sludge. Difficulties in analyzing the low plutonium concentrations in solution before and after the acid contact leave some uncertainty with respect to the amount of plutonium dissolved. However, the generally low solubility of plutonium oxalates would predict poor removal using oxalic acid. The tests with the Tank 5F sludge sample used a carbon steel coupon inserted into the oxalic acid/sludge mixture to include the potential effect of corrosion on sludge dissolution and gas generation. Measurements of the gases evolved during the test identified carbon dioxide as the primary component with some nitrogen oxides present.

Table 2-1. Estimated Percentage of Key Elements Dissolved from the Tank 5F Sludge

\begin{tabular}{|l|c|c|}
\hline Analyte & $\begin{array}{c}\text { Percentage } \\
\text { Dissolved in } \\
\mathbf{5 0}^{\circ} \mathbf{C} \text { Test }\end{array}$ & $\begin{array}{c}\text { Percentage } \\
\text { Dissolved in } \\
\mathbf{7 5}^{\circ} \mathbf{C} \text { Test }\end{array}$ \\
\hline $\mathrm{Fe}$ & 62 & $\mathbf{7 6}$ \\
\hline $\mathrm{U}$ & 73 & 87 \\
\hline $\mathrm{Mn}$ & 40 & 59 \\
\hline $\mathrm{Ni}$ & 0.1 & 0.1 \\
\hline $\mathrm{Al}$ & 84 & 107 \\
\hline${ }^{238} \mathrm{Pu}$ & 2.9 & 2.9 \\
\hline${ }^{239 / 240} \mathrm{Pu}$ & 3.2 & 2.9 \\
\hline
\end{tabular}


Additionally, tests were conducted using a sludge simulant to determine corrosion rates and gases generated during oxalic acid cleaning operations in support of Tank $5 \mathrm{~F}$ chemical cleaning. ${ }^{7}$ These tests attempted to closely follow the key steps in the oxalic acid cleaning flowsheet including the length of time for acid addition and expected agitation levels. The simulant tests at $25^{\circ} \mathrm{C}, 50{ }^{\circ} \mathrm{C}$ and $75^{\circ} \mathrm{C}$ found similar levels of sludge dissolution and evolved gas compositions as observed in the real waste tests with the Tank $5 F$ sludge sample. Corrosion rates of the carbon steel coupons placed in the test apparatus were found to vary with coupon orientation, temperature, and level of agitation in the test vessel. Neutralization of the decanted oxalic acid cleaning solutions precipitated solids with a mass from $60 \%$ to $143 \%$ of the initial sludge mass.

Recently in Tanks 5F and 6F, the first contact of oxalic acid with the sludge heel showed moderate success with respect to sludge dissolution. The flowsheet for oxalic acid cleaning of waste tanks calls for one 20:1 strike with $8 \mathrm{wt} \%$ oxalic acid (oxalic acid to sludge heel volume) followed by two $13: 1$ strikes at $50{ }^{\circ} \mathrm{C}$. After bulk waste removal, Tank 5F contained about 3500 gal of sludge heel. ${ }^{9}$ Approximately 70,000 gal of $8 \mathrm{wt} \%$ oxalic acid was added to the tank. An additional 55,000 gal of water was added to bring the level in the tank up to the 45 inches needed to operate the mixing pumps. Mapping of the tank floor after the first acid contact indicated about 2750 gal of heel still remains in the tank. Analysis of liquid samples from the tank after the oxalic acid contact indicate a large fraction of the aluminum ( $78 \%$ ) and uranium ( 100\%), and some of the manganese ( $\sim 40 \%)$ in the sludge heel dissolved. ${ }^{10}$ However, only $\sim 15 \%$ of the iron in the sludge heel was present in the oxalic acid solution. The low iron concentration in solution indicates that either the oxalic acid was not effective in dissolving the iron, or the iron dissolved and then re-precipitated. A measurement of the post contact solution found a $\mathrm{pH}$ of 4 , which may have caused the precipitation of iron oxalate. The dissolution of iron oxides (hematite and magnetite) with oxalic acid has been studied and shows a dependency on $\mathrm{pH}$, oxalic acid concentration, and temperature. ${ }^{11}$

Tank 6F contained approximately 6000 gal of sludge heel after bulk waste removal. ${ }^{12}$ The first oxalic acid contact of 120,000 gal of $8 \mathrm{wt} \%$ oxalic acid brought the sludge heel volume down to 2400 gal. Approximately $60 \%$ of the sludge was dissolved or removed from the tank, showing good agreement with experimental results. A measurement of the post contact solution from Tank 6F found a $\mathrm{pH}$ of 2 . The difference between the cleaning procedures used in Tank 5F and Tank 6F appears to be the addition of a large volume of water to Tank 5F after the $8 \mathrm{wt} \%$ oxalic acid addition, and the $\mathrm{pH}$ of the resulting solutions in each tank after contacting the sludge heel. The added water diluted the oxalic acid from $8 \mathrm{wt} \%$ to $\sim 4 \mathrm{wt} \%$ in Tank 5F.

Stallings and Hobbs at SRNL reported on the results of lab scale testing using solutions of 4 wt $\%$ oxalic acid alone and in combination with citric acid. ${ }^{13}$ The tests used $4 \mathrm{wt} \%$ oxalic acid, as recommended by previous work from a Russian team of researchers. ${ }^{14}$ Simulated sludge as well as actual waste tank sludge samples from Tank 8F and Tank 12H (PUREX and HM sludge types respectively) were used in the tests. However, the waste tank sludge 
samples had dried out over the years the samples were stored, possibly affecting the solubility of the sludge in the acids.

Among the conclusions of the Stallings and Hobbs study were the following:

- The citric acid-oxalic solution outperformed the $4 \mathrm{wt} \%$ oxalic acid even though it had fewer total acid protons $(0.547 \mathrm{M}$, protons, versus $1.18 \mathrm{M}$ protons for $4 \mathrm{wt} \%$ oxalic acid).

- Caustic leaching of aluminum was less efficient at dissolving aluminum than was the treatment program of oxalic acid or oxalic plus citric acid solutions.

- $\quad$ Oxalic-citric acid mixtures produce a more homogeneous distribution of sludge species between phases, including the radionuclides.

- $\quad$ Oxalic-citric acid mixtures were not unusually corrosive to carbon steel.

- Increased sludge dissolution occurred with higher acid to sludge ratios (50:1) versus the lower recommended ratio of 2:1.

- $\quad$ Uranium dissolved more completely than other species in the sludge leaving a higher ratio of neutron poisons to ${ }^{235} \mathrm{U}$ in the residual solids.

Test conducted at Hanford examined a large number of potential cleaning agents including oxalic acid. ${ }^{15}$ These tests employed five common sludge components in place of a simulated sludge. Each of these components $\left(\mathrm{Fe}(\mathrm{OH})_{3}, \mathrm{Al}(\mathrm{OH})_{3}, \mathrm{MnO}_{2}, \mathrm{Cr}(\mathrm{OH})_{3}\right.$, and $\left.\mathrm{Na}_{2} \mathrm{U}_{2} \mathrm{O}_{7}\right)$ were tested individually with each of the prospective cleaning agents. The study found that $\mathrm{Fe}(\mathrm{OH})_{3}$ was the most difficult component to dissolve. Only oxalic acid and HF dissolved more than $40 \%$ of the $\mathrm{Fe}(\mathrm{OH})_{3}$. Oxalic acid was found to be the most effective cleaning agent tested. Although oxalic acid dissolved all of the components to some extent, it did not completely dissolve the $\mathrm{Fe}(\mathrm{OH})_{3}$ and $\mathrm{MnO}_{2}$. Oxalic acid dissolution of $\mathrm{MnO}_{2}$ produced a large amount of off-gas compared to most other tests as well as formation of new solids believed to be $\mathrm{Mn}(\mathrm{II})$ oxalate. Oxalic acid also led to a new precipitate for $\mathrm{U}$, which was presumed to be uranyl oxalate trihydrate.

The Hanford tests also examined nitric acid-oxalic acid combinations. Uranium and manganese achieved higher dissolutions in intermediate blends than in either pure acid, while $\mathrm{Cr}, \mathrm{Al}$, and Fe followed fairly linear trends, i.e. the behavior of these three elements could be linearly interpolated using the results from the pure nitric acid and pure oxalic acid tests. Combinations of citric acid with oxalic acid showed the potential to keep the uranium and manganese in solution following their initial dissolution from the precipitated solids. The primary usefulness of citric acid appeared to be as a complexing agent once insoluble Fe, $\mathrm{Mn}$, and $\mathrm{U}$ were dissolved by another acid such as oxalic acid.

The results described above and from the previous literature review indicate that oxalic acid appears reasonably effective at dissolving sludge heels. The main issues with the use of 
oxalic acid for chemical cleaning results from the large mass of sodium oxalate salts added to the tank farm after neutralization of the cleaning solution. The amount of oxalic acid needed for tank cleaning could potentially be minimized by any combination of:

- More effective mechanical cleaning prior to chemical cleaning will reduce the volume of sludge heels requiring chemical treatment.

- $\quad$ Optimizing the oxalic acid cleaning process through defining the minimum acid requirements for a sludge heel.

- Using a higher concentration mineral acid for neutralization of the sludge/supernate prior to oxalic acid addition and for controlling the $\mathrm{pH}$ after oxalic acid addition.

\subsection{OPTIMIZING MECHANICAL CLEANING}

A separate team comprised of complex-wide expertise in retrieval is collecting and assessing technical information that identifies mechanical cleaning options and optimization strategies. ${ }^{16}$ However, improved effectiveness of mechanical cleaning prior to starting chemical cleaning would reduce the volume of oxalic acid required for chemically cleaning a tank. Current practice employs two to three large bulk waste removal slurry pumps which leaves dead zones in the tank where mounds of sludge can form. Furthermore, the pumps require a large volume of liquid in the tank for operation and must be shut down as the slurry level in the tank drops to about forty-inches leading to settling of the sludge particles before reaching the transfer pump. The presence of coiling coils in the tank further complicates mechanical sludge removal by providing additional areas for sludge mounds to form.

The two main issues facing current mechanical cleaning methods relate to initial suspension of the sludge and keeping the sludge in suspension until the transfer pumps remove it from the tank. Based on recent experience in Tanks 5F and 6F, the difficulty of keeping the sludge in suspension using current mechanical methods appears to be preventing the removal of the final small volume of sludge waste from the tanks. ${ }^{17}$ Mapping of the sludge mounds during bulk waste removal from these two tanks showed the mounds moved around within the tank after each cleaning cycle. The four sludge tanks cleaned to date did not show evidence of hardened sludge mounds that could not be broken apart by the slurry pumps. However, at least one tank at SRS undergoing waste removal does contain hardened material that could not be removed using slurry pumps. ${ }^{18}$

Mechanical cleaning of the sludge heel may require a different approach than bulk waste removal. Retrieval areas suggested for further evaluation include: ${ }^{19}$

- $\quad$ Use of pumps that can operate in a few inches of liquid so that at least some minimal amount of mixing can continue throughout the transfer. More pumps than currently used for bulk waste removal will be required to provide reasonable coverage over the tank bottom. The key objective of mechanical cleaning at low sludge volumes will be to keep the sludge in suspension until it reaches the transfer pump. 
- Use of movable or multiple transfer pumps allowing the suction to be placed near the sludge mounds or near the mixing pumps as needed to remove the sludge. Available riser openings in the tank roof may limit access to area of the tank and the number of pumps that can be deployed.

- Water washing or sluicing with water (or inhibited water) to peptize the sludge particles making them easier to keep suspended. Reducing the ionic strength of the liquid associated with the sludge, typically to less than $\sim 0.1 \mathrm{M} \mathrm{Na}$, allows the agglomeration of small particles that make up a typical sludge particle to break apart. ${ }^{20,21}$ These smaller particles settle much more slowly and will stay in suspension throughout the transfer. This option adds additional water to the tank farm but does not add any additional salts or very little salt in the case of inhibited water usage. The water washing would also reduce the basicity of the remaining sludge heel, which would further reduce oxalic acid usage. The peptized sludge particles should re-agglomerate when placed back in high ionic strength liquid. However, the re-agglomeration of the peptized sludge particles should be confirmed in the laboratory to avoid settling problems when the sludge is processed through sludge washing.

Additionally, a recent review of tank closure progress in the DOE complex provides overviews of mechanical cleaning methods being implemented or tested at other sites. ${ }^{22}$ This document provides a starting point for those interested in further information on mechanical cleaning of waste tanks.

\subsection{OPTIMIZING OXALIC ACID USAGE}

The current oxalic acid cleaning flowsheet calls for the use of a 20:1 ratio of $8 \mathrm{wt} \%$ oxalic acid to sludge heel volume. The flowsheet used a number of past studies conducted on oxalic acid dissolution of sludge as the basis for the acid concentration and acid to sludge ratio. Most of these studies of sludge dissolution using oxalic acid were discussed in the previous review. Some of the variables that must be addressed for optimization of the oxalic acid cleaning process include:

- $\quad$ Acid concentration

- $\quad$ Contact time

- $\quad$ Temperature

- Volume of acid to sludge heel

- $\mathrm{pH}$

Most of the past studies indicate a higher extent of sludge dissolution with increasing acid concentration. However, some data shows the same sludge dissolution effectiveness with 4 $\mathrm{wt} \%$ oxalic acid as with $8 \mathrm{wt} \%$ oxalic acid in a multi-step chemical cleaning process thereby reducing oxalic acid usage by a factor of $2 .^{23}$

Many of the past studies of oxalic acid dissolution of sludge used only short contact times between the acid and the sludge, typically less than 24 hours. A study conducted at Hanford 
site contacting sludge with $9 \mathrm{wt} \%$ oxalic acid indicates the iron, aluminum, and manganese concentrations in the acid continued to rise for the 18 day duration of the test. ${ }^{24}$

All of the information examined on the dissolution of sludge using oxalic acid shows increasing temperature dissolves sludge faster than lower temperatures.

The volume ratio of oxalic acid to sludge volume also appears to be a significant factor in how much sludge dissolves. Most of the past work seems to indicate a ratio of 20:1 oxalic acid volume to sludge volume provides the maximum dissolution of sludge solids. Lower ratios appear to be less effective and higher ratios only slightly more effective at dissolving sludge solids. However, there appears to be significant variability in the data from past studies with regard to the concentration and volume ratios of oxalic acid required for effective dissolution of the sludge. Some of the variability may result from test procedures that used sludge simulants versus actual tank sludge, methodologies that relied on volume measurements versus mass loss or solution concentrations to determine sludge dissolution, and a wide range of sludge compositions. Most of the studies used a pre-defined volume ratio of oxalic acid to sludge regardless of the type and characteristics of the sludge. This volumetric approach may also account for the seemingly contradictory results in some cases since different sludge composition (and associated supernate solution) may have very different acid requirements for effective dissolution.

Most, if not all of the past studies did not control the $\mathrm{pH}$ of the oxalic acid solution contacting the sludge. The high ratios of oxalic acid to sludge heel volume required for effective dissolution probably result from the need to drive the $\mathrm{pH}$ below 3 . The lack of control of the solution $\mathrm{pH}$ may contribute to some of the variability in dissolution effectiveness found in the body of data on oxalic acid dissolution of sludge. Controlling the solution $\mathrm{pH}$ and providing the required amount of oxalic acid based on the sludge composition may represent the biggest areas for process optimization. Instead of adding a fixed ratio of oxalic acid to sludge volume, the required amount of oxalic acid should be determined based on the sludge composition and volume.

\subsection{SLUDGE HEEL NEUTRALIZATION WITH MINERAL ACIDS}

The sludge heel in a waste tank contains base equivalents that consume some portion of the oxalic acid before sludge dissolution begins. This neutralization step could be better accomplished using a stronger acid. Replacing oxalic acid with a mineral acid (nitric acid or sulfuric acid) could help reduce the amount of oxalate added to the tank farm. The corrosion issues associated with using mineral acids in the carbon steel waste tanks will need to be addressed. However, most of the mineral acid would be consumed during the neutralization of the sludge heel. Additionally, the use of a mineral acid may help dissolve manganese, nickel, plutonium, americium, and curium which dissolve poorly or form insoluble oxalate complexes in oxalic acid. 


\subsection{IMPACTS OF OXALATE ON THE DOWNSTREAM PROCESSES}

The previous review of chemical cleaning options contains a good description of the impact of large quantities of oxalate salts on downstream processes such as waste tanks storing the material, the evaporator system, and the DWPF. ${ }^{3}$ There has been little additional information generated in the intervening years into the impacts of oxalic acid cleaning on downstream processes. However, a process flowsheet for the baseline chemical cleaning process has been developed. ${ }^{1}$

Chemical cleaning using oxalic acid results in two waste streams containing oxalate salts that could affect downstream processes. These two streams, resulting from the $\mathrm{pH}$ adjustment of the spent acid cleaning solutions, include a high $\mathrm{pH}$ supernatant solution containing dissolved oxalate salts and a sludge slurry of precipitated insoluble metal hydroxides and metal oxalates (predominantly sodium oxalate). The preferred flowsheet would transfer the high $\mathrm{pH}$ supernatant solution to the evaporator drop tank. ${ }^{1}$ The sodium oxalate associated with this stream would crystallize, becoming part of the saltcake waste ultimately processed through the SWPF. The sludge slurry containing precipitated sodium oxalate would preferably be added to a washed sludge batch and be processed with the sludge through the DWPF. A steady low concentration of oxalate salts in the sludge feed is preferable to any single sludge batch containing high concentrations of oxalate. Testing indicates the DWPF Sludge Receipt and Adjustment Tank (SRAT) could process sludge with up to $26 \mathrm{wt} \%$ sodium oxalate, however, glass performance considerations might lower that limit to $10 \mathrm{wt} \%$. The flowsheet assumes a 5000 gallon heel and modeling results indicate 65,000 gallons of $8 \mathrm{wt} \%$ oxalic acid will be required for dissolution of F-Area sludge heels and 85,000 gallons for H-Area sludge heels. Recent oxalic acid cleaning in Tanks 5F and 6F exceeded these volume to remove only a portion of the sludge heel. ${ }^{9,12}$

Clearly, a large volume of oxalate solids and solutions will likely impact downstream processes to some extent and adds to the volume of waste requiring treatment. Every effort should be made to minimize the quantity of oxalic acid used in tank cleaning. If efforts to minimize the volume of oxalic acid used do not reduce the amount of oxalate salts to levels acceptable to downstream processes, then a process for destroying oxalate would be needed or an alternative process that does not rely on oxalic acid must be developed for chemical cleaning of sludge heels. 


\subsection{OXALIC ACID DESTRUCTION TECHNOLOGIES}

Various processes for the destruction of oxalic acid have been investigated that could potentially be used to reduce the amount of oxalate added to the tank farm inventory from tank cleaning. These processes include a number of chemical oxidation methods, electrochemical oxidation, the use of ultra-violet light, and advanced oxidation processes utilizing hydroxyl free radicals to oxidize oxalic acid. Many of these oxidation processes have been developed for use in treating dilute industrial wastewaters containing low concentrations of oxalic acid and other organic contaminants. Partial oxidation of organics in wastewaters many times results in the production of the more difficult to oxidize oxalic acid as a byproduct. As a result, oxalic acid has been used as a model compound for evaluating methods for the oxidation of organic contaminants in wastewaters. The scientific literature contains a very large number of papers pertaining to the subject of the oxidation of organic compounds. Therefore, the review was limited to providing only a few references to each of the oxidation processes described in the following sections.

\subsection{CHEMICAL OXIDATION OF OXALIC ACID}

Several different chemical oxidation processes can be used for the destruction of oxalic acid. These chemical oxidation processes include:

$\begin{array}{ll}\text { - } & \mathrm{KMnO}_{4} \\ \text { - } & \mathrm{K}_{2} \mathrm{Cr}_{2} \mathrm{O}_{7} \\ \text { - } & \mathrm{H}_{2} \mathrm{O}_{2} \\ \text { - } & \text { Ozone } \\ \text { Nitric Acid - Mn(II) catalyzed }\end{array}$

Potassium (or sodium) permanganate $\left(\mathrm{KMnO}_{4}\right)$ and potassium dichromate $\left(\mathrm{K}_{2} \mathrm{Cr}_{2} \mathrm{O}_{7}\right)$ are common reagents for oxidizing organic compounds. ${ }^{25-27}$ Oxidations with these reagents are typically carried out at low $\mathrm{pH}$ for complete oxidation of organics. However, the oxidations with $\mathrm{KMnO}_{4}$ can be effective over a wide range of $\mathrm{pH}$ values and even under strongly basic conditions. ${ }^{28-29}$ The oxidative destruction of oxalic acid appears to be slower and less efficient as the $\mathrm{pH}$ of the solution increases. At low $\mathrm{pH}$ oxalic acid is readily oxidized by $\mathrm{KMnO}_{4}{ }^{30-31}$ Reaction rates increase with increasing temperature but the reactions can be carried out at ambient temperatures $\left(\sim 20^{\circ} \mathrm{C}\right)$. Potassium permanganate has been used for destruction of oxalic acid in $\mathrm{H}$-canyon processing, ${ }^{32-33}$ investigated for oxidative leaching of Cr(III) from Hanford HLW sludge, ${ }^{34}$ and as a means for strontium and actinide element removal from HLW. ${ }^{35}$ Due to the stoichiometry of these reactions, the use of these oxidants for the destruction of oxalic acid from chemical cleaning could add substantial amounts of $\mathrm{Mn}$ or Cr to the tank farm.

$2 \mathrm{MnO}_{4}{ }^{-}+3 \mathrm{C}_{2} \mathrm{O}_{4}{ }^{2-}+8 \mathrm{H}^{+} \rightarrow 2 \mathrm{MnO}_{2}+6 \mathrm{CO}_{2}+4 \mathrm{H}_{2} \mathrm{O}$

Hydrogen peroxide $\left(\mathrm{H}_{2} \mathrm{O}_{2}\right)$ will oxidize oxalic acid and generates no additional waste volume, but according to the reference, will not oxidize oxalic acid complexed with metals. ${ }^{36}$ 
Considering the high potential reward of no additional waste being generated, some simple scoping tests to confirm this statement seem justified. The reaction of $\mathrm{H}_{2} \mathrm{O}_{2}$ with complexed oxalic acid could just be kinetically slow and therefore appeared to not react over the short time frame of the tests. Hydrogen peroxide is also added as an additional oxidant to an ozonation processes, Fenton oxidations, and ultra violet radiation (UV) processes to increase the effectiveness of the oxidation. (see Section 3.4 on AOP's)

Ozonation alone appears effective at partially oxidizing many organic molecules found in wastewaters but usually will not oxidize the organics completely to $\mathrm{CO}_{2}$ and water. Oxalic acid, as one of the by-products of this partial oxidation, is not efficiently destroyed by ozonation. Typically, these ozonation methods have only been tested on dilute aqueous solutions containing much lower concentrations of oxalic acid $(<0.01 \mathrm{M})$ than the concentrations expected from dissolving sludge (typically $>0.5 \mathrm{M}=\sim 4 \mathrm{wt} \%$ oxalic acid). A review of the scientific literature on ozonation shows a trend toward combination processes to increase the effectiveness of the oxidation of difficult to oxidize organics such as oxalic acid. A large number of papers can be found using ozonation coupled with metal catalysts, and/or one of the other oxidizing reagents listed above, for the destruction of oxalic acid. ${ }^{37-41}$ (see Section 3.4) Similar to the hydrogen peroxide oxidation, ozonation has the potential of generating no additional waste as long as presence of partially oxidized organics can be ignored.

A nitric acid-Mn(II) catalyzed process for the oxidation of oxalic acid was developed at SRS as a means for destruction of the oxalic acid from cleaning Tank $16 \mathrm{H}^{36}{ }^{36}$ The process requires only a small concentration of manganous ion, typically $0.01 \mathrm{M}$ to $0.02 \mathrm{M}$, in 1 - $4 \mathrm{M}$ nitric acid to catalyze the oxidation of oxalic acid by the nitric acid under refluxing conditions. The reaction consumes nitric acid producing carbon dioxide, water, and potentially oxides of nitrogen depending upon the reaction conditions. The $\mathrm{pH}$ adjustment of the solutions resulting from oxalic acid destruction would add $\mathrm{NaNO}_{3}$ and manganese oxides to the tank farm waste inventory in place of large amounts of sodium oxalate. Because the manganese acts as a catalyst in this oxidation process, only a small amount of Mn would be added to the tank farm relative to the potassium permanganate process discussed previously. Tests of the process typically found greater than $99 \%$ percent destruction of the oxalic acid. This same process has been used in the recovery of Am/Cm at SRS. ${ }^{42-44}$

A Technical Data Summary for the nitric acid-Mn(II) catalyzed process contains detailed information on the chemistry and reaction kinetics developed from testing with both simulated and actual sludge samples. The scale of the tests ranged from small laboratory scale tests to demonstrations in a one fifth scale semi-works chemical cleaning facility. Additionally, the process has been demonstrated on a plant scale in F-Canyon where 20 tons of oxalic acid was destroyed using the nitric acid-Mn(II) catalyzed process. ${ }^{36,45}$ The FCanyon campaign oxidized forty-three batches of $\sim 0.6 \mathrm{M}$ oxalic acid in an evaporator using a combination of continuous and reflux modes. The oxidation can be used in batch or continuous processes with or without volume reduction. The Technical Data Summary also contains a conceptual flowsheet using existing plant equipment and examined flow rates, offgas production, nuclear criticality, and corrosion issues. 
West Valley also evaluated the nitric acid-Mn(II) catalyzed process for destroying oxalate from tank cleaning and confirmed that it was feasible. ${ }^{46}$

\subsection{ELECTROCHEMICAL OXIDATION OF OXALIC ACID}

As with ozonation, a large body of data exists in the scientific literature on the development of electrochemical oxidation processes for treating wastewater streams containing organic contaminants. Oxalic acid, other carboxylic acids, and small organic molecules generated from the partial electrochemical oxidation of many organics, typically become the terminal product of the oxidation. Further oxidation of these difficult to oxidize organics may not be practical in treatment of wastewaters due to the lower efficiency and higher cost. The development of methods for the electrolytic oxidation of organics, including oxalic acid, using conventional noble-metal (Pt, Pd) electrodes has been limited by the large overpotential required to break the $\mathrm{C}-\mathrm{C}$ bond and the sensitivity to inhibition (or surface fouling) by numerous other species. ${ }^{47-50}$ The electrode material strongly affects the efficiency of the electrochemical process especially for oxalic acid since surface absorption may be involved with the reaction mechanism. Many types of materials have been investigated to find electrodes with high stability and selectivity including $\mathrm{IrO}_{2}, \mathrm{PbO}_{2}$, graphite. ${ }^{51}$ Recent interest has extended to boron-doped diamond electrodes and use of solid polymer electrolyte reactors. ${ }^{52-55}$ Most of the electrochemical oxidation work focused on destruction of low concentrations of oxalic acid although some studies used up to $0.1 \mathrm{M}$ oxalic acid. The scientific literature shows oxalic acid can be destroyed by electrochemical methods however at lower efficiencies and rates than more easily oxidized organics.

\subsection{ULTRA VIOLET RADIATION FOR OXIDATION OF OXALIC ACID}

Ultra violet radiation (UV) can be used to destroy oxalic acid and other organics. ${ }^{56}$ However, since the mechanism of the oxidation involves both direct and indirect (hydroxyl free radicals) mechanisms, the use of UV for organic destruction in wastewaters typically falls under the heading of an advanced oxidation processes (see Section 3.4). Additionally, in most of the articles reviewed, hydrogen peroxide (or ozone) was added to increase the rate of destruction by increasing the generation of hydroxyl free radicals. Oxalic Acid (0.3 M) in a nitric acid or hydrochloric acid waste stream from plutonium processing can be destroyed with the addition of $\mathrm{H}_{2} \mathrm{O}_{2}$, but the rate and amount destroyed increases dramatically with the addition of UV light. ${ }^{57}$ The efficiency of UV oxidation processes decreases as opacity of the solution increases, so application to the treatment of a slurry containing a significant amount of suspended solids seems potentially problematic. A patent describes a method for cleaning a surface with oxalic acid and then converting the spent oxalate to $\mathrm{CO}_{2}$ using UV light. The iron(III) oxalate generated from the surface cleaning is converted to iron(II) oxalate plus $\mathrm{CO}_{2}{ }^{58}$

\subsection{ADVANCED OXIDATION PROCESSES}

Advanced oxidation processes (AOP) utilize hydroxyl free radicals to oxidize organic contaminants in a waste stream. The hydroxyl free radicals can be generated from a number of different processes including; $\mathrm{O}_{3} / \mathrm{H}_{2} \mathrm{O}_{2}, \mathrm{UV} / \mathrm{O}_{3}, \mathrm{UV} / \mathrm{H}_{2} \mathrm{O}_{2}, \mathrm{UV} / \mathrm{H}_{2} \mathrm{O}_{2} / \mathrm{O}_{3}$, Fenton processes 
(Fe(II)), and photocatalytic processes $\left(\mathrm{UV} / \mathrm{TiO}_{2}\right) .{ }^{59-61}$ Because these AOP's use radicals to oxidize the organic contaminants, the presence of radical scavengers, such as carbonate and nitrite anions, in the waste stream can decrease the efficiency of the process. As with ozonation and electrochemical oxidation, most of the literature relating to AOP's focused on dilute wastewater streams or drinking water disinfection. The concentrations of oxalic acid used in the studies were generally much lower than the concentrations expected from tank cleaning operations.

The main advantage of $\mathrm{O}_{3} / \mathrm{H}_{2} \mathrm{O}_{2}$ over simple ozonation is the increased reaction rate due to the increased production of hydroxyl free radicals. The oxidizing power of the $\mathrm{O}_{3} / \mathrm{H}_{2} \mathrm{O}_{2}$ does not increase much over $\mathrm{O}_{3}$ alone and therefore can still lead to incomplete destruction of some organics. The use of UV with added peroxide or ozone produces higher yields of hydroxyl radicals and therefore more complete oxidation of organics. The use of $\mathrm{H}_{2} \mathrm{O}_{2}$ has the advantage of low cost commercial availability, high solubility in water, and the ability to store the material on-site. Ozone has a higher absorption cross section than hydrogen peroxide and generates hydroxyl radicals more efficiently, but suffers from lower solubility in water and the mass transfer issues associated with gases. The $\mathrm{UV} / \mathrm{H}_{2} \mathrm{O}_{2} / \mathrm{O}_{3}$ process has been found to be a more efficient treatment than any other combination of these three oxidation methods. $^{59,62}$

UV irradiation of dispersions of $\mathrm{TiO}_{2}$ in wastewaters can generate hydroxyl radicals on the surface of the $\mathrm{TiO}_{2}$ catalyst for the oxidation of organic contaminants. The UV/TiO 2 can use both the UV-A and UV-B regions of the spectrum potentially allowing for the use of solar radiation as the UV source. ${ }^{62-64}$

\subsection{OTHER OXIDATION PROCESSES}

Several other oxidation processes were encountered during the literature survey that were not evaluated for various reasons. These include; steam reforming, ${ }^{65}$ wet air oxidation, ${ }^{66}$ wet peroxide oxidation, ${ }^{67}$ enzymatically catalyzed degradation, ${ }^{68,69}$ a pulse corona-discharge process, ${ }^{70}$ ultrasonic assisted oxidations, $^{71}$ and sonophotocatalysis. ${ }^{72,73}$ 


\subsection{ALTERNATIVE CHEMICAL CLEANING TECHNOLOGIES}

Alternative chemical cleaning technologies are taken to mean technologies other than bulk oxalic acid cleaning or technologies that supplement oxalic acid cleaning. Some of the alternate chemical cleaning technologies examined below were also covered in previous reviews. In these instances, the focus will be on new data generated since the previous review.

\subsection{OTHER ACIDS}

A significant amount of research has been reported investigating the use of acids other than oxalic acid for dissolving sludge and major sludge components (Fe, $\mathrm{Al}, \mathrm{Mn}, \mathrm{U}$ compounds). Most of these studies were covered in the previous review. ${ }^{3}$ Those four elements (Fe, $\mathrm{Al}, \mathrm{Mn}$, $\mathrm{U})$ make up the majority of the material in SRS HLW sludge. Additionally, a search of the scientific literature shows that the chemistry associated with dissolving various $\mathrm{Fe}, \mathrm{Al}, \mathrm{Mn}$, and $U$ phases in acids is well represented with respect to mechanism and kinetics of the dissolution. Unfortunately, mechanistic and kinetic testing is typically conducted at low concentrations so little information could be found with respect to maximum solubility of the mineral phases in acids.

\subsubsection{Sinkov Review of Various Treatments}

As discussed briefly in Section 2.1, Sinkov examined a large number of potential cleaning agents on five common sludge components in place of a simulated sludge. ${ }^{14}$ Each of these components $\left(\mathrm{Fe}(\mathrm{OH})_{3}, \mathrm{Al}(\mathrm{OH})_{3}, \mathrm{MnO}_{2}, \mathrm{Cr}(\mathrm{OH})_{3}\right.$, and $\left.\mathrm{Na}_{2} \mathrm{U}_{2} \mathrm{O}_{7}\right)$ was tested individually with each of the prospective cleaning agents. Table 4.1 summarizes cleaning agents tested on the five common sludge compounds. The study focused on the dissolution aspect of heel removal with little information on dealing with the spent cleaning solutions.

None of the agents tested dissolved all of the solids completely, but oxalic and hydrofluoric acid were found to be the most effective. The $\mathrm{Fe}(\mathrm{OH})_{3}$ was the most difficult to dissolve of the five phases tested with $\mathrm{MnO}_{2}$ being the next most difficult. The $\mathrm{Na}_{2} \mathrm{U}_{2} \mathrm{O}_{7}$ was the phase most easily dissolved. Oxalic acid was found to be the most effective reagent dissolving all the phases to some extent.

Sinkov also tested nitric acid-oxalic acid combinations at constant total molarity. Uranium and manganese achieved higher dissolutions in intermediate blends than in either pure acid, while $\mathrm{Cr}, \mathrm{Al}$, and Fe followed fairly linear trends, i.e. the behavior of these three elements could be linearly interpolated using the results from the pure nitric acid and pure oxalic acid tests. 
Table 4-1. Dissolution Agents Selected for Testing by Sinkov ${ }^{15}$

\begin{tabular}{|c|c|c|}
\hline Chemical Class & Agent & Formula \\
\hline \multirow[t]{4}{*}{ Carboxylic acids } & Acetic acid & СН3CO2H \\
\hline & Oxalic acid & $(\mathrm{HO} 2 \mathrm{C}) 2$ \\
\hline & Malonic acid & $\mathrm{HO} 2 \mathrm{CCH} 2 \mathrm{CO} 2 \mathrm{H}$ \\
\hline & Phthalic acid & o-C6H4(CO2H)2 \\
\hline \multirow[t]{6}{*}{ Hydroxycarboxylic acids } & Glycolic acid & $\mathrm{CH} 2 \mathrm{OHCO} 2 \mathrm{H}$ \\
\hline & Lactic acid & НO2ССНОНСН3 \\
\hline & Tartaric acid & $\mathrm{HO} 2 \mathrm{C}(\mathrm{CHOH}) 2 \mathrm{CO} 2 \mathrm{H}$ \\
\hline & Gluconic acid & $\mathrm{HO} 2 \mathrm{C}(\mathrm{CHOH}) 4 \mathrm{CH} 2 \mathrm{OH}$ \\
\hline & Citric acid & $\mathrm{HO} 2 \mathrm{CCH} 2 \mathrm{C}(\mathrm{OH}) \mathrm{CO} 2 \mathrm{HCH} 2 \mathrm{CO} 2 \mathrm{H}$ \\
\hline & Salicylic acid & o-C6H4(OH)COOH \\
\hline \multirow[t]{2}{*}{ Alcohol } & Catechol & o-C6H4(OH)2 \\
\hline & Tiron & $\begin{array}{l}\text { 4,5-dihydroxy-1,3-benzenedisulfonic acid, } \\
\text { disodium salt }\end{array}$ \\
\hline \multirow[t]{2}{*}{ Carboxylate salts } & K2Oxalate & $(\mathrm{KO} 2 \mathrm{C}) 2$ \\
\hline & Na3Citrate & $\mathrm{NaO} 2 \mathrm{CCH} 2 \mathrm{C}(\mathrm{OH}) \mathrm{CO} 2 \mathrm{NaCH} 2 \mathrm{CO} 2 \mathrm{Na}$ \\
\hline \multirow{5}{*}{$\begin{array}{l}\text { Aminocarboxylic } \\
\text { acids/salts }\end{array}$} & Glycine & HO2CCH2NH2 \\
\hline & Na2IDA & $(\mathrm{NaO} 2 \mathrm{CCH} 2) 2 \mathrm{NH}$ \\
\hline & Na3NTA & $(\mathrm{NaO} 2 \mathrm{CCH} 2) 3 \mathrm{~N}$ \\
\hline & H2Na2EDTA & $(\mathrm{NaO} 2 \mathrm{CCH} 2) 2 \mathrm{~N}(\mathrm{CH} 2) 2 \mathrm{~N}(\mathrm{CH} 2 \mathrm{CO} 2 \mathrm{H}) 2$ \\
\hline & Na3HEDTA & $\begin{array}{l}(\mathrm{NaO} 2 \mathrm{CCH} 2) 2 \mathrm{~N}(\mathrm{CH} 2) 2 \mathrm{~N}(\mathrm{CH} 2 \mathrm{CH} 2 \mathrm{OH}) \\
\mathrm{CH} 2 \mathrm{CO} 2 \mathrm{Na}\end{array}$ \\
\hline Hydroxamic acid & $\begin{array}{l}\text { Acetohydroxamic } \\
\text { acid }\end{array}$ & CH3CONHOH \\
\hline \multirow[t]{2}{*}{ Mineral acids } & Nitric acid & HNO3 \\
\hline & Hydrofluoric acid & $\mathrm{HF}$ \\
\hline
\end{tabular}

In spite of Sinkov's conclusions, it was noted in the raw data tables that HF was more effective than oxalic acid for iron, aluminum, and uranium dissolution (three out of four species known to be significant in SRS waste). Oxalic acid outperformed HF on Mn 
dissolution, but at the expense of forming a new precipitate. Oxalic acid also led to a new precipitate for $\mathrm{U}$, which was presumed to be uranyl oxalate trihydrate. An HF cleaning process could potentially out perform oxalic acid in mobilizing SRS wastes. However, an HF cleaning process would have significant corrosion and industrial hygiene issues, and potentially some downstream impacts.

The single compound heat-treated simulants used in the screening tests had aged approximately six months by the time of the acid combination tests. It was noted that the efficiency of $0.5 \mathrm{M}$ oxalic acid in dissolving $\mathrm{Fe}(\mathrm{OH})_{3}$ dropped from $38 \%$ in the fresh simulant to $7 \%$ in the aged simulant in 40 hour tests. This was tentatively attributed to formation of the more refractory oxyhydroxide, $\mathrm{FeOOH}$, over the six months aging period. Similar behavior was seen for $\mathrm{Cr}(\mathrm{OH})_{3}$. However, the dissolution rate of the iron oxyhydroxides may simply be slower (rate limited versus equilibrium limited) such that oxalic acid would dissolve a higher percentage of the material if the contact time was extended. This observation points to the importance of knowing what phases are present in prepared simulants and using phases that accurately reflect the material being simulated.

Oxalic acid dissolution of $\mathrm{MnO}_{2}$ produced a large amount of off-gas compared to most other tests as well as formation of new solids believed to be Mn(II) oxalate. Citric acid, tartaric acid, and lactic acid completely dissolved $\mathrm{Mn}$ and $\mathrm{U}$ but were ineffective on $\mathrm{Al}$ and Fe. The Mn re-precipitated in the test with tartaric acid. Combinations of citric acid with oxalic acid showed the potential to keep the uranium and manganese in solution following their initial dissolution from the precipitated solids. The primary usefulness of citric acid appeared to be as a complexing agent once insoluble Fe, Mn, and U were dissolved by another acid such as oxalic acid.

Sinkov performed a literature review prior to his testing. Highlights of his review include:

- Acid dissolution of hydroxides of $\mathrm{Al}$ and $\mathrm{Cr}$ has been studied the most, but dissolution of isomorphous combination compounds where $\mathrm{Cr}$ substitutes for $\mathrm{Al}$ or vice versa have not been studied.

- Conditions to dissolve $\mathrm{Fe}(\mathrm{OH})_{3}$ require a combination of reducing media, acid conditions, and chelating agents. Kinetics rather than thermodynamics controls the dissolution when these conditions are met. Dissolution of $\mathrm{Fe}_{2} \mathrm{O}_{3}$ (hematite) is more difficult than the hydroxide or oxyhydroxide dissolutions.

- Dissolution of $\mathrm{MnO}_{2}$ is promoted by choosing an acid that will cause reductive dissolution, such as formic acid, oxalic acid, etc., rather than an inorganic acid such as $\mathrm{HNO}_{3}$ or $\mathrm{HCl}$.

- $\mathrm{Pu}(\mathrm{IV})$ dissolution was difficult and proceeded slowly in reviewed work. This was attributed to polymerization of the hydrous oxides. Fe(III) appeared to inhibit $\mathrm{Pu}$ dissolution when competing for the same complexing ligands. 
- Many of the tests were performed at higher temperatures that exceeded the likely cleaning conditions at Hanford.

- The survey did not identify any class of solubilizing agent that could be expected to dissolve all five major species with high efficiency.

\subsubsection{Chen Decontamination Review}

Chen et al. did a thorough review of decontamination technologies in $1997 .^{74}$ The survey was fairly comprehensive with more than 50 chemical decontamination technologies reviewed. Potential applications of these technologies as gels or foams, instead of as solutions, were also discussed as a potential waste volume reduction strategy. Many of the technologies evolved from processes for the decontamination of stainless steels.

Treatment options for carbon steels included in the report examined acid cleaning methods, often with inhibiting agents to reduce corrosion. These included sulfamic acid, nitric acid, oxalic acid, and citric acid, mixed organic acids, and combinations of nitric acid with either $\mathrm{HF}$ or HCl. Peroxide containing solutions constituted another class of cleaning methods. Four systems containing $\mathrm{H}_{2} \mathrm{O}_{2}$, oxalic acid, plus a third acid were reviewed. The third acid used in these systems was either hydrothermic acid, HF, citric acid, or gluconic acid.

Inhibited $\mathrm{HCl}$ was more commonly used on carbon steel than on stainless steel. Some positive aspects of using $\mathrm{HCl}$ included low cost, easy inhibition, good reaction with corrosion products (metal oxides), and highly soluble waste salts. Nitric acid was not considered feasible for carbon steel systems in the context of short contact time cleaning operations due to the high corrosion rates, however it was recognized for its ability to dissolve $\mathrm{U}$ and $\mathrm{Pu}$ oxides. Sulfuric acid could be used in inhibited form on carbon steel with potentially comparable results to $\mathrm{HCl}$, but forms low solubility sulfate salts with $\mathrm{Ca}, \mathrm{Ba}$, and $\mathrm{Sr}$ (minor components of HLW sludge). Phosphoric acid treatments apparently required temperatures in the $75-85^{\circ} \mathrm{C}$ range. Sulfamic acid was also typically used at elevated temperatures, $45-80^{\circ} \mathrm{C}$, and often required a series of treatments. Treatments using nitric acid with either $\mathrm{HF}$ or $\mathrm{HCl}$ were typically limited to stainless steel equipment, due to potentially high corrosion rates with carbon steels. A nitric acid-HF mixture was used to clean the PUREX pilot plant at Oak Ridge. The review points out that fumes from HF can damage off-gas equipment not designed from corrosion resistant materials.

Oxalic acid was noted for its excellent ability at removing rust and in complexing fission products. Citric acid was not considered a very effective solvent by itself for metal oxides, but it functions to buffer the $\mathrm{pH}$, promote $\mathrm{Fe}^{3+}$ solubility, and to reduce the quantity of ferrous oxalate precipitates in systems with oxalic acid. Addition of $\mathrm{H}_{2} \mathrm{O}_{2}$ to oxalic acid has a range of effects. At low concentration, peroxide acts as a corrosion promoter, while at higher concentrations it acts as a corrosion inhibitor. One advantage of peroxide is that it decomposes to water and oxygen with no anticipated downstream impacts. Peroxide also passivates metal surfaces. One disadvantage is that oxalic acid and $\mathrm{H}_{2} \mathrm{O}_{2}$ react slowly to consume the oxalic acid. Equipment decontamination of thin films is fast enough that 
cleaning occurs before consumption, but the cleaning solution needs to be used as made and not stored for future use.

\subsubsection{Shields Chemical Cleaning Review}

Shields reports on the chemical cleaning methods for steam generators in power plants. ${ }^{75}$ The review covers the acids generally employed for the removal of iron oxides from steam generators. These acids include, $\mathrm{HCl}, \mathrm{HF}$, hydroxyacetic-formic acid (HAF), ethylenediaminetetraacetic acid (EDTA), and citric acid. The report contains typical concentrations, temperatures, and contact times for each acid and a table of individual metal oxide carrying capacity for each acid. Shields reports that although avoided in North America, HF dissolutions are fairly rapid, and cleaning times are fairly short, compared to other compounds used for removing iron oxide deposits. He also reports that HF was effective at cleaning aluminum oxides, calcium salts (except sulfates), and silica. An alternative to handling and using HF solutions that is popular in North America is to use $\mathrm{HCl}$ combined with ammonium bifluoride, $\mathrm{NH}_{4} \mathrm{~F} \cdot \mathrm{HF}$, which produces $\mathrm{HF}$ after the two are combined in aqueous solution.

\subsubsection{Wang-Stone Mn Dissolution Paper}

The authors of this paper report on the dissolution of various forms of manganese including $\mathrm{MnO}_{2}$ and $\mathrm{MnOOH} .^{76}$ Manganese is a major SRS insoluble sludge component. Dissolution testing included oxalic acid, phosphonoformic acid, glyoxylic acid, and ten additional organic compounds. These included pyruvic acid, 2,3-butanedione, oxamic acid, lactic acid, and dimethyl oxalate (not all of these are acids). All thirteen species reacted with $\mathrm{MnO}_{2}$ by reductive dissolution that yielded $\mathrm{Mn}(\mathrm{II})$ at room temperature (to the extent that they reacted at all). Urea was not effective in dissolving $\mathrm{MnO}_{2}$. Fosamine was the slowest dissolver of the other twelve organics. Dissolution rate data are included in the paper. The authors concluded that of the thirteen species, only oxalic acid could produce a stable complex at a $\mathrm{Mn}$ oxidation state above two. They concluded that an Mn(III) oxalate complex should be stable at about $\mathrm{pH} 5.0$ but not at $\mathrm{pH}$ 6.0. The other chemicals drove the Mn from Mn(IV) to Mn(II) without any stable intermediate complexes at oxidation states three or four. It appears from the data that at least one form of $\mathrm{MnO}_{2}$ is unstable with respect to water once $\mathrm{pH}$ falls below 3.5 (delta form).

The paper includes a reference to a thorough review of $\alpha$-hydroxycarboxylic acid-metal ion complex stability. These compounds contain two donor groups, a hydroxyl group and a carboxylate group. Thus, they are all potentially bidentate ligands. An example is 2hydroxyacetic acid (glycolic acid). Lactic acid also falls in this class of compounds. The relative position of the two donor groups on the molecule has a strong impact on its complexing behavior. The elements listed in the metal complex tables for various individual acids include many of the insoluble cations in sludge waste.

\subsubsection{Powell Paper on U(VI) and Boehmite}

An abstract for this paper indicates that addition of 1-hydroxyethane-1,1-diphosphonic acid (HEDPA) enhanced dissolution of $\mathrm{Al}(\mathrm{III})$ in the form of boehmite (AlOOH) in the $\mathrm{pH}$ range 
SRNL-STI-2009-00500, REV. 0

of $4-9 .{ }^{77}$ The Al(III) was complexed by the HEDPA. The HEDPA also promoted U(VI) dissolution in this range.

\subsubsection{Al-Hobaib Paper on Ra Desorption, Mn, and Fe Reductive Dissolution}

This group of researchers studied the removal of radium adsorbed on iron and manganese oxides/hydroxides held on sand filter particles. The radium removal was accomplished via reductive dissolution using organic acids. ${ }^{78}$ The authors ranked the acids for radium removal efficiency as oxalic acid $>$ phthalic acid $>$ adipic acid $>$ succinic acid $>$ formic acid $>$ acetic acid. The amount of radium removed was also found to equate with dissolution of the iron and manganese oxides/hydroxides from the sand filters.

The authors also examined $\mathrm{Mn}$ and Fe dissolution as part of the study and concluded that dissolution is fastest to slowest in the sequence: $\mathrm{Mn}(\mathrm{OH})_{2}>\gamma-\mathrm{MnOOH}>\mathrm{MnO}>\mathrm{Mn}_{2} \mathrm{O}_{3}>$ $\mathrm{MnO}_{2}>\mathrm{Fe}(\mathrm{OH})_{3}>\alpha-\mathrm{FeOOH} \geq \gamma-\mathrm{FeOOH}>\mathrm{Fe}_{3} \mathrm{O}_{4}>\mathrm{Fe}_{2} \mathrm{O}_{3}$. so dissolution of aged iron oxides would represent the greatest challenge to SRS among the species studied.

The three elements ( $\mathrm{Ra}, \mathrm{Fe}, \mathrm{Mn}$ ) had dissolution kinetics that followed first-order behavior in the insoluble compound concentration in the presence of a given acid. Radioactive decay follows first-order kinetics in the element isotope concentration, so achieving high extents of compound dissolution corresponds to achieving high fractions of decay (if $50 \%$ dissolves in one week, then $75 \%$ dissolves in two weeks, $87.5 \%$ in three weeks, etc.). The authors also reported that manganese formed a manganese oxalate precipitate during treatment.

\subsubsection{Enda et al. Patent (Formic acid-Oxalic acid)}

A patented process for chemical decontamination was reviewed. ${ }^{79}$ The patent is of note in that the researchers tested formic acid-oxalic acid mixed solutions for cleaning. Dissolution of hematite $\left(\mathrm{Fe}_{2} \mathrm{O}_{3}\right)$ was minimal with formic acid only. Dissolution of hematite with the combined acid solution, however, was reported as both significantly faster and more extensive than with simple oxalic acid solution. The testing was done at elevated temperatures. In the patented process the spent acid cleaning solution was treated with $\mathrm{H}_{2} \mathrm{O}_{2}$, which destroyed both the formate ions (fast) and the oxalate ions (slow, needed help from ozone, hydrogen permanganate, or potassium permanganate).

\subsection{CAUSTIC CHEMICAL CLEANING}

Caustic (sodium hydroxide) addition can be used to dissolve aluminum from sludge waste. A caustic aluminum dissolution process has been used at SRS and tested at other DOE sites in the past. ${ }^{80-82}$ Recently, a low temperature aluminum dissolution (LTAD) process was used to remove aluminum from sludge at SRS. Both a laboratory scale demonstration and the full scale process removed $40-60 \%$ of the aluminum at $55-65{ }^{\circ} \mathrm{C}$ over a 3-5 week contact period. ${ }^{83,84}$ Data from the LTAD testing indicates the process was very selective for aluminum with no other species in the sludge matrix dissolving to any appreciable extent. A more recent demonstration of the LTAD process also dissolved $\sim 60 \%$ of the aluminum from Tank $12 \mathrm{H}$ sludge. ${ }^{85}$ Both the gibbsite and boehmite forms of aluminum can be removed using the LTAD process. ${ }^{86}$ 
The selectivity of caustic treatment of sludge waste for aluminum somewhat limits its applicability as a chemical cleaning agent. Acids have been found to dissolve aluminum more effectively depending on the acid and the form of the aluminum. ${ }^{6,13}$ However, for high aluminum sludge heels containing a significant fraction of the boehmite phase, caustic treatment might be a useful first step prior to use of an acidic chemical cleaning agent. Using caustic to dissolve the aluminum from the sludge may help with mobilizing sludge mounds that are difficult to break up using conventional mechanical methods. The Hanford site has apparently used caustic treatment to aid in mobilizing sludge from waste tank S-112 although no supporting documentation could be found.

A caustic addition process coupled with the addition of triethanolamine (TEA) appears to increase the dissolution rate of aluminum and other metal presents in the sludge. ${ }^{87}$ Tank $12 \mathrm{H}$ sludge from SRS contacted with a leaching solution of $3 \mathrm{M} \mathrm{NaOH}$ and $3 \mathrm{M}$ TEA at $60{ }^{\circ} \mathrm{C}$ found the percentage of aluminum dissolved increased from $35 \%$ to $87 \%$ compared to contact with a leaching solution containing no TEA. Over $50 \%$ of the iron dissolved in the 10 day tests with a leaching solution of $3 \mathrm{M} \mathrm{NaOH}$ and $3 \mathrm{M} \mathrm{TEA}$ at $60^{\circ} \mathrm{C}$, while essentially no iron dissolved in the test without TEA.

\subsection{ORGANIC COMPLEXANTS}

Several investigators have examined and/or reviewed chemical cleaning methods for sludgelike solids using organic complexants. ${ }^{3,15,74}$ Certain potential cleaning compounds demonstrated effectiveness on select individual sludge species, but generally none of the compounds tested showed potential for being broadly effective on a wide range of insoluble hydrous oxides. To find a compatible set of compounds that would collectively dissolve a significant fraction of HM and PUREX sludge mounds in one or two strikes appears to be a daunting task. New methods in high-speed chemical screening have been developed in the past decade or so, and it might nevertheless be possible to test enough of the potential combinations to find one that works using this technology (potentially hundreds of chemical combinations to test). However, screening for each sludge heel composition may be necessary. Equipment requirements and potential advantages of the technologies need to be part of that evaluation.

Of the compounds studied, the EDTA-based solvents were very popular in the above referenced works. EDTA forms stable complexes with iron, nickel, and some other di- and tri-valent cations. Sinkov looked at $\mathrm{H}_{2} \mathrm{Na}_{2}$ EDTA and $\mathrm{Na}_{3} \mathrm{HEDTA}$. These were poor dissolvers of $\mathrm{Al}$ and Fe hydroxides, but the first was fairly effective on $\mathrm{MnO}_{2}$ and sodium diuranate. Catechol and Tiron (alcohols) were able to dissolve sodium diuranate, but were ineffective on hydroxides of $\mathrm{Al}, \mathrm{Fe}$, and $\mathrm{Cr}$, and on $\mathrm{MnO}_{2}$. No encouraging data were found to indicate that an organic complexant would be a magic bullet for sludge heel removal.

An element by element search of the technical literature would likely produce a list of complexing agents tailored to individual salts. For example, water soluble EDTA-diazacrown ether polymers dissolve barium sulfate, which is a minor species in sludge waste. ${ }^{88}$ Sodium spiroboronate can apparently dissolve copper(II) hydroxide. ${ }^{89}$ Fluoride ion is apparently a complexant for aluminum and this may be related to the efficiency of HF solutions in 
dissolving $\mathrm{Al}(\mathrm{OH})_{3}$. Uranium can apparently form uranyl carbonate complexes. ${ }^{90}$ Alternatively, many of the complexants needed for the insoluble hydroxides in tank waste may not have been invented and/or discovered yet, and a search for a multi-complexant cleaning solution might be fruitless.

Additional care must be taken in developing organic chemical based cleaning technologies. Not all organic chemicals will be compatible with each other, with SRS waste, and with downstream SRS equipment/processes. For example, sodium nitrate present in waste tank heels forms nitric acid if the $\mathrm{pH}$ is dropped, and nitric acid attacks many organic compounds. Not all organic compounds are soluble in water over a wide range of $\mathrm{pH}$, and the formation of immiscible organic liquid layers would be seen as generally undesirable in DWPF, in the tank farm, etc. This problem would be magnified if one or more radionuclides preferentially separated into the organic layer. Ring compounds in the feed to the DWPF SRAT have tended to form tarry linked-ring compounds in the presence of nitrite during acid addition. DWPF also has limits on total organic carbon in the melter feed in order to avoid melter offgas flammability issues.

Organic contaminants in the SWPF feed could potentially disrupt the liquid-liquid extraction system for recovering cesium. DWPF has flammability limits that have already been impacted by the SWPF design which introduced a limited quantity of organics into the Chemical Process Cell (CPC). These are in the form of limits on the total organic carbon content of the melter feed. DWPF also has issues with foaming in the CPC, so even low volatility biphilic compounds should be avoided because of their potential to act as surfactant foam stabilizers. Given the list of potential downstream issues with complicated organic compounds, it would appear that a destruction strategy would have to accompany the cleaning technology in order to effectively remove the organics from the streams moving downstream to SWPF and DWPF.

While research in the area of complicated organic complexants for tank cleaning is not entirely discouraged, the point is being made that whole new classes of potential processing issues are raised that are not present with inorganic and simple organic compounds.

\subsection{INDUSTRIAL PROCESSES}

A recent examination of industrial decontamination processes as a possible alternative to the baseline oxalic acid cleaning flowsheet evaluated six relevant technologies. ${ }^{91}$ The industrial processes evaluated included:

- LOMI - Low Oxidation Metal Ion

- Can-Decon - CANDU Decontamination

- CITROX - Citric Oxalic with Exchange

- DfD - Decontamination for Decommissioning

- DfDx - Decontamination for Decommissioning-Adv.

- CORD-UV - Chemical Oxidation Reduction Decontamination-UV 
All of these processes use oxalic acid as part of the chemical decontamination system with the exception of the LOMI process. The evaluation indicated the Reduction-UV segment of the CORD-UV process as the optimal solution. The Reduction-UV segment of the CORDUV process would include the addition of oxalic acid to dissolve the sludge waste and the UV portion to destroy the oxalic acid, re-precipitating the dissolved metals of the sludge. The typical industrial use of the CORD-UV process use a permanganic acid oxidation followed by oxalic acid addition to bring the decontamination products into solution. ${ }^{92}$ During the decontamination, ion exchange resins continuously purify and regenerate the solution. Ultra violet radiation in combination with ozone or hydrogen peroxide subsequently destroys the oxalic acid at the end of the cycle. The process produces water, $\mathrm{CO}_{2}$, and spent ion exchange resin containing the radioactivity and corrosion products.

These industrial decontamination processes were designed to clean radioactively contaminated corrosion films by chemically dissolving the metal oxide film liberating the trapped radionuclides. The application of these technologies to SRS waste tank heel cleaning should be feasible, although some modifications and troubleshooting will be necessary due the larger mass of metal oxides requiring dissolution. In fact, the CORD-UV process proposed for SRS will use a solid/liquid separation step in place of ion exchange to remove the metal oxides from the dissolution stream. ${ }^{93}$ This change of configuration results from the larger mass of solids and the desire to minimize secondary waste streams such the spent ion exchange resin. The UV oxalate destruction step may also encounter difficulties due to the in situ formation of insoluble solids that can block the UV light and potentially foul equipment. 


\subsection{DISCUSSION AND CONCLUSIONS}

\subsection{GENERAL DISCUSSION ON THE LITERATURE REVIEW}

The objective of this literature review was to build on the previous review ${ }^{3}$ and identify any new information or potential technologies relating to chemical cleaning of sludge heels from waste tanks. A team was charged with evaluating the information in these reviews and developing a recommendation of alternative technologies to pursue. However, the new information in this report seems to buttress the conclusion of the previous review that oxalic acid remains the chemical cleaning agent of choice for dissolving the metal oxides and hydroxides found in sludge heels in carbon steel tanks. That conclusion should not be surprising given that oxalic appears to be the industry standard for chemical cleaning and decontamination of corrosion products in the power generation industry. Oxalic acid shows the ability to dissolve most of the metal oxides and hydroxides as well as or better than other acids at low acid concentrations and has lower corrosion rates on carbon steel than most other acids.

The use of oxalic acid for chemical cleaning can result in the formation of large amounts of sodium oxalate after neutralization of the cleaning solutions. The potential negative impact of large volumes of sodium oxalate on downstream processes indicates that the amount of oxalic acid used for chemical cleaning needs to be minimized as much a possible or the oxalic acid must be destroyed prior to $\mathrm{pH}$ adjustment in the receipt tank.

The most straightforward way of minimizing the volume of oxalic acid needed for chemical cleaning is through more effective mechanical cleaning. One of the key problems with current mechanical cleaning appears to be keeping the sludge in suspension until it reaches the transfer pump. Extensive water washing/sluicing may provide a means for peptizing the sludge, which will help keep the sludge in suspension longer. The water washing will also reduce the basicity of the sludge heel further reducing the volume of acid needed for chemical cleaning.

Using a mineral acid to adjust the $\mathrm{pH}$ of the sludge prior to adding oxalic acid to the waste tank may also help to minimize the volume of oxalic acid used in chemical cleaning. If minimization of oxalic acid proves insufficient in reducing the volume of oxalate salts, several methods were found that could be used for oxalic acid destruction.

The approach used in developing a chemical cleaning strategy with oxalic acid needs to be more chemically focused. The dissolution chemistry of the major metal oxides present in sludge heels (Fe, $\mathrm{Al}, \mathrm{U}, \mathrm{Mn}$ ) has been well characterized in the scientific literature with respect to the mechanism and kinetics of the dissolution. ${ }^{11,94-102}$ Iron oxide dissolution (hematite and magnetite) in oxalic acid has been the focus of a large amount of research due to the impact of corrosion products on boilers or other metal parts in contact with moisture in the industrial sector. The dissolution of iron shows a dependency on acid concentration, $\mathrm{pH}$, and temperature. The right combination of these variables along with good characterization data on the sludge heel is required to dissolve the metal oxides and prevent re-precipitation. 
Inattention to all the variables could probably explain some of the seemingly contradictory results from previous sludge heel chemical cleaning studies. Control of the $\mathrm{pH}$ during oxalic cleaning may represent the most promising area for process optimization. Due to the variations in waste tank heel composition, the cleaning strategy should be tailored to each tank based on sample characterization.

The metal oxide phases present in the sludge will affect test results since some phases dissolve more easily than others. Typically the more hydrated phases dissolve more easily than less hydrated phases (i.e., $\mathrm{Fe}(\mathrm{OH})_{3}>\alpha$-FeOOH $\geq \gamma$-FeOOH $>\mathrm{Fe}_{3} \mathrm{O}_{4}>\mathrm{Fe}_{2} \mathrm{O}_{3}$ ). As part of sludge heel sample characterization, XRD should be used to provide data on metal oxide phases present realizing that a significant portion of the sludge may be amorphous. Obtaining XRD data for real sludge samples has been limited due to the high dose rates. However, analysis of the Sludge Batch $1 \mathrm{~B}$ found iron in the form of hematite $\left(\mathrm{Fe}_{2} \mathrm{O}_{3}\right)$ and aluminum as boehmite $(\mathrm{AlO}(\mathrm{OH}))$ in an XRD analysis. ${ }^{21}$ Similarly, XRD analysis of Sludge Batch 4 found boehmite, hematite and lepidocrocite $(\mathrm{FeO}(\mathrm{OH}))$ as the primary crystalline phases present in the sludge. ${ }^{103}$ Hematite and boehmite phases have also been identified in Hanford sludge waste. ${ }^{15}$ Simulated sludge used for testing should be analyzed by XRD also to confirm the correct metal oxide phases were prepared.

For some waste tank heels, another acid or even caustic treatment (or pretreatment) might be more appropriate. Heels containing large amounts of compounds that do not dissolve well in oxalic acid, such as aluminosilicates/zeolites, might require the use of another acid to dissolve the material. Nitric acid, hydrochloric acid or sulfuric acid might be appropriate for dissolving small amounts of non-sludge waste tank heels. These acids can be inhibited to reduce corrosion rates to some extent and, used in small amounts, should not impact down stream processes. Caustic treatment of high aluminum sludge heels could be used as a means of reducing oxalic acid usage. After water washing to remove the caustic, and possibly $\mathrm{pH}$ adjustment with a mineral acid, less oxalic acid will be needed to remove the remaining metal oxides left behind in the tank.

Reagents other than oxalic acid may also be needed for removing actinide elements from the tank heels. Although oxalic acid appears to dissolve many of the materials found in sludge heels, it does not appear effective at dissolving some of the radionuclides, such as plutonium, americium, and curium that contribute to the source term after tank closure.

Industrial decontamination and corrosion removal processes appear to have some application to chemical cleaning of sludge heels since most of these processes include the use of oxalic acid. However, due to the magnitude of the material being removed in sludge heel removal versus the typical application of these technologies, some development work and potentially some equipment modifications would be required before implementation.

\subsection{RESULTS OF THE TECHNOLOGY EVALUATION}

A systems' engineering evaluation (SEE) was performed on the various alternative chemical cleaning reagents and oxalic acid destruction methods (organic oxidation technologies) discussed in this review. ${ }^{104}$ The objective of the evaluation was to develop a short list of 
chemical cleaning reagents and oxalic acid destruction methods that should be the focus of further research and development. The evaluation considered the general categories individually, as shown in the list below, rather than all the various combinations chemical cleaning reagents and organic oxidation technologies that might be coupled to make an enhanced chemical cleaning process.

\section{List of Alternatives for Technology Evaluation}

Alternative Chemical Cleaning Technologies/Reagents

(to enhance, replace, or partially offset the use of oxalic acid)

1. Complexants (EDTA, $\mathrm{H}_{2} \mathrm{Na}_{2}$ EDTA, $\mathrm{Na}_{3} \mathrm{HEDTA}$, others)

2. Organic Acids (oxalic, citric, formic)

3. Mineral Acids (nitric, sulfuric, hydrochloric, hydrofluoric)

4. Caustic Treatment (primarily for Al)

5. Combinations

- oxalic + other cleaning agents

- sequential caustic and acid treatment

- complexants (including citric with organic destruction)

\section{Organic Oxidation Technologies for Enhanced Chemical Cleaning}

(to remove oxalic acid and other organic cleaning agents from the system)

1. Chemical Oxidation Processes

- $\mathrm{KMnO}_{4}$

$-\mathrm{K}_{2} \mathrm{Cr}_{2} \mathrm{O}_{7}$

$-\mathrm{H}_{2} \mathrm{O}_{2}$

$-\mathrm{O}_{3}$

- Nitric acid w/ Mn(II) catalysis

2. Advanced Oxidation Processes (AOP)

$-\mathrm{O}_{3} / \mathrm{H}_{2} \mathrm{O}_{2}$

$-\mathrm{UV} / \mathrm{O}_{3}$

- $\mathrm{UV} / \mathrm{H}_{2} \mathrm{O}_{2}$

- $\mathrm{UV} / \mathrm{H}_{2} \mathrm{O}_{2} / \mathrm{O}_{3}$

- Fenton Processes - Fe(II)

- Photocatalytic Processes $\left(\mathrm{UV} / \mathrm{TiO}_{2}\right)$

3. Direct UV Processes

4. Electrochemical Processes

The results of the SEE found that eight of the thirteen organic oxidation technologies scored relatively close together. These eight processes recommended for further research and development include: five of the advanced oxidation processes $\left(\mathrm{UV} / \mathrm{O}_{3}, \mathrm{UV} / \mathrm{H}_{2} \mathrm{O}_{2}\right.$, $\mathrm{UV} / \mathrm{O}_{3} / \mathrm{H}_{2} \mathrm{O}_{2}, \mathrm{O}_{3} / \mathrm{H}_{2} \mathrm{O}_{2}$, and Fenton's process), two of the chemical oxidation processes (nitric acid with $\mathrm{Mn}(\mathrm{II})$ catalysis and $\mathrm{KMnO}_{4}$ oxidation) and the direct UV process. Six of the chemical cleaning reagents were also recommended for further investigation. These included: combinations of oxalic acid and nitric acid, oxalic acid with other organic acids, 
oxalic acid with other mineral acids, oxalic acid with complexants, sequential caustic and acid treatment, and dilute mineral acids.

\subsection{RECOMMENDATIONS FOR FUTURE WORK}

Based on the results of the SEE and plan set out in the TTQAP the following broad areas are recommended for future study as part of the AECC task.

- Basic Chemistry of Sludge Dissolution in Oxalic Acid: A better understanding of the variables effecting dissolution of sludge species is needed to efficiently remove sludge heels while minimizing the use of oxalic acid or other chemical reagents. Tests should investigate the effects of $\mathrm{pH}$, acid concentration, phase ratios, temperature, and kinetics of the dissolution reactions of sludge components with oxalic acid, mineral acids, and combinations of oxalic/mineral acids. Real waste sludge samples should be characterized to obtain additional data on the mineral phases present in sludge heels.

- Simulant Development Program: Current sludge simulants developed by other programs for use in waste processing tests, while compositionally similar to real sludge waste, generally have more hydrated forms of the major metal phases and dissolve more easily in acids. Better simulants containing the mineral phases identified by real waste characterization should be developed to test chemical cleaning methods.

- Oxalic Acid Oxidation Technologies: The two Mn based oxidation methods that scored highly in the SEE should be studied to evaluate long term potential. One of the AOP's (UV/O ${ }_{3} /$ Solids Separator) is currently being implemented by the SRS liquid waste organization for use in tank heel chemical cleaning.

- Corrosion Issues: A program will be needed to address potential corrosion issues from the use of low molarity mineral acids and mixtures of oxalic/mineral acids in the waste tanks for short durations. The addition of corrosion inhibitors to the acids to reduce corrosion rates should be investigated. 


\subsection{REFERENCES}

1. Pike, J. A., Badheka, N. P., Ketusky, E. T., Flowsheet for SRS Waste Tank Heel Removal Using Oxalic Acid, WSRC-TR-2004-00317, Rev. 0, Savannah River Site, November 2004.

2. $\quad$ King, W. D., Task Technical and Quality Assurance Plan for EM-21 Enhanced Chemical Cleaning Studies for Sludge Heel Removal, WSRC-RP-2008-00613, Rev. 0, Savannah River Site, May 2008.

3. Adu-Wasu, K., M. J. Barnes, N. E. Bibler, J. R. Cantrell, F. F. Fondeur, B. A. Hamm, C. C. Herman, D. T. Hobbs, E. T. Ketusky, M. Singleton, M. E. Stallings, W. E. Stevens, and B. J. Wiersma, Waste Tank Heel Chemical Cleaning Summary, WSRCTR-2003-00401, Rev. 0, Savannah River Site, September 2003.

4. West, W. L., Tank 16 Demonstration - Wash Water and Chemical Cleaning Results, DPSP-80-17-23, December 1980.

5. Fong, M. C. H., Oxalic Acid Cleaning of Tank 24H, DPST-85-782, Rev. 0, Savannah River Site, September 1985.

6. Hay, M. S., Crapse, K. P., Fink, S. D., Pareizs, J. M., Characterization and Actual Waste Tests with Tank 5F Samples, WSRC-STI-2007-00192, Rev. 1, Savannah River Site, August 2007.

7. Herman, D. T., Wiersma, B. J., Fondeur, F. F., Wittkop, J. C., Pareizs, J. M., Crapse, K. P., Hay, M. S., Poirier, M. R., Fink, S. D., Investigating Hydrogen Generation and Corrosion in the Treatment Tank and the Potential Formation of a Floating Layer in Neutralization Tank during Waste Tank Heel Chemical Cleaning, WSRC-STI-200700209, Rev. 0, Savannah River Site, April 2007.

8. Vemulapalli, R. N., Tanks 5 and 6 Oxalic Acid Aided Heel Removal Flowsheet, LWOPIT-2006-00066, Rev. 2, Savannah River Site, November 2007.

9. Ludwig, W. C., Tank 5 Solids Volume Estimation After the First Chemical Cleaning, M-ESR-F-00150, Rev. 0, Savannah River Site, August 2008.

10. Poirier, M. R., Tank 5 and Tank 7 Chemical Cleaning Sample Analysis, SRNL-CST2008-00045, Savannah River Site, July 2008.

11. Lee, S. O., Dissolution of Iron Oxides by Oxalic Acid, Doctoral Thesis, The University of South Wales-School of Chemical Engineering and Industrial Chemistry, Sydney, Australia, 2005. 
12. Ludwig, W. C., Tank 6 Solids Volume Estimation After the First Chemical Cleaning, M-ESR-F-00153, Rev. 0, Savannah River Site, August 2008.

13. Stallings, M. E., D. T. Hobbs, and B. J. Wiersma, Dissolution of Simulated and Radioactive Savannah River Site High-Level Waste Sludges with Oxalic Acid and Citric Acid Solutions, WSRC-TR-2004-00043, Rev. 0, Savannah River Site, March 2004.

14. Lubtsev, R., Revenko, Y., V. G. Khlopin Radium Institute and Mining Chemical Combine Final Report for the Project Russian Chemical Decontamination of Tanks (Phase 2), St. Petersburg, 2000.

15. Sinkov, S., Candidate Reagents for Dissolution of Hanford Site Tank Sludges Scoping Studies with Simulants Using Single Reagents and Their Mixtures, PNNL14378, Pacific Northwest National Laboratory, August 2003.

16. Fellinger, A.P. Berglin, E.J, Rinker, M.W, Minichan, R.L., EM-21 Retrieval Knowledge Center: Waste Retrieval Challenges, SRNL-STI-2009-00231 (PNNL18356), April 2009.

17. Jolly, R. C., Completion of Mechanical Bulk Sludge Removal in Tank 5, LWO-LWE2008-00124, Rev. 0, May 2008

18. Swingle, R. F., Bibler, N. E., Ekechukwu, A. A., Data Report: Tank 19F NE Riser Zeolite Mound Sample Analysis, WSRC-RP-2001-00410, Savannah River Site, April 2001.

19. Fellinger, A.P. et.al., EM-21 Retrieval Knowledge Center Technical Report: Mobilize and Dislodge Tank Waste Heels, SRNL-STI-2009-00535, September 2009. (Draft)

20. Motyka, T., Technical Data Summary for In-Tank Sludge Processing, DPSTD-84-100, Savannah River Site, April 1984.

21. Hay, M. S., Bibler, N. E., Characterization and Sludge Washing Studies of Tank 42H Sludge, WSRC-RP-94-730, Savannah River Site, July 1994.

22. Langton, C. A., Cook, J. R., Recent Progress in DOE Waste Tank Closure, WSRC-STI2007-00686, Savannah River Site, January 2008.

23. Hyder, M. L., Recommended Oxalic Acid Concentration for Chemical Dissolving of Tank 16H Sludge, DPST-78-436, Savannah River Site, July 1978.

24. Bechtold, D. B., Cooke, G. A., Herting, D. L., Person, R. S., Viswanath, R. S., Warrant, R. W., Laboratory Testing of Oxalic Acid Dissolution of Tank 241-C-106 Sludge, RPP17158, Rev. 0, Fluor Hanford, Richland, WA, July 2003. 
25. Hasan, F., Rocek, J., Cooxidation of Isopropyl Alcohol and Oxalic Acid by Chromic Acid. A One-Step Three electron Oxidation, J. Am. Chem. Soc., 94, (1972), 3181-3187.

26. Dash, S., Patel, S., Mishra, B. K., Oxidation by Permanganate: Synthetic and Mechanistic Aspects, Tetrahedron, 65, (2009), 707-739.

27. Huang, K., Hoag, G. E., Pradeep, C., Woody, B. A., Dobbs, G. M., Kinetics and Mechanism of Oxidation of Tetrachloroethylene with Permanganate, Chemosphere, 46, (2002), 815-825.

28. Chang, H., Korshin, G. V., Ferguson, J. F., Woody, Investigation of Mechanisms of Oxidation of EDTA and NTA by Permangante at High pH, Environ. Sci. Technol., 40, (2006), 5089-5094.

29. Shaker, A. M., Based-Catalyzed Oxidation of Carboxymethyl-cellulose Polymer by Permanganate, J. Colloid Interface Sci., 233, (2001), 197-204.

30. Alder, S. J., Noyes, R. M., The Mechanism of the Permanganate-Oxalate Reaction, J. Am. Chem. Soc., 77, (1955), 2036-2042.

31. Ganapathisubramanian, N., Role of Free Radicals and Reaction-Diffusion Phenomena in the Autocatalytic Permanganate-Oxalate Reaction, J. Phys. Chem., 92, (1988), 414417.

32. Hill, B. C., Bronikowski, M. G., Gas Generation during Sodium Permanganate Addition to HB-Line Phase II Filtrate Tank, WSRC-TR-2002-00350, Savannah River Site, August 2002.

33. Gray, J. H., The Formation and Dissolution of plutonium Oxalate Solids in HB-Line Phase II Filtrate Streams, WSRC-TR-2001-00317, Savannah River Site, July 2001.

34. Rapko, B. M., Lumetta, G. J., Deschane, J. R., Peterson, R. A., Process Development for Permanganate Addition During Oxidative Leaching of Hanford Tank Sludge Simulants, PNNL-16794, Pacific Northwest National Laboratory, October 2007.

35. Barnes, M. J., Hobbs, D. T., Duff, M. C., Fink, S. D., Permanganate Reduction of Savannah River Site Actual Waste Samples for Strontium and Actinide Removal, WSRC-TR-2002-00048, Savannah River Site, February 2002.

36. Bibler, N. E., J. E. Hoisington, and E. W. Holtzscheiter, Technical Data Summary: Decomposition of Oxalic Acid by the Manganese Catalyzed Nitric Acid Reaction, DPSTD-80-36, Rev. 0, Savannah River Site, March 1981.

37. Avramsecu, S. M., Bradu, C., Udrea, I., Mihalache, N., Ruta, F., Degradation of Oxalic Acid from Aqueous Solutions by Ozonation in Presence of $\mathrm{Ni}_{\mathrm{Al}} \mathrm{O}_{3}$ Catalysts, Catalysis Communications, 9, (2008), 2386-2391. 
38. Beltran, F., J., Rivas, F. J., Montero-de-Espinosa, R., Iron Type Catalysts for the Ozonation of Oxalic Acid in Water, Water Research, 39, (2005), 3553-3564.

39. Andreozzi, R., Caprio, V., Insola, A., Marotta, R., Tufano, V., Kinetics of Oxalic Acid Ozonation Promoted by Heterogeneous $\mathrm{MnO}_{2}$ Catalysis, Ind. Eng. Chem. Res., 36, (1997), 4774-4778.

40. von Guten, U., Ozonation of Drinking Water: Part I. Oxidation Kinetics and Product Formation, Water Research, 37, (2003), 1469-1487.

41. von Guten, U., Ozonation of Drinking Water: Part II. Disinfection and By-Product Formation in the Presence of Bromide, Iodide, or Chloride, Water Research, 37, (2003), 1443-1467.

42. Gray, L. W., Burney, G. A., Wilson, T. L., McKibben, J. M., Separation of Am-Cm from $\mathrm{NaNO}_{3}$ Waste Solutions by In-Canyon-Tank Precipitation as Oxalates, DP-1539, Savannah River Site, September 1981.

43. Gray, L. W., Burney, G. A., Wilson, T. L., McKibben, J. M., Bibler, N. E., Holtzscheiter, E. W., Campbell, T. G., Separation of Am-Cm from Al $\left(\mathrm{NO}_{3}\right)_{3}$ Waste Solutions by In-Canyon-Tank Precipitation as Oxalates, DP-1572, Savannah River Site, April 1982.

44. Gray, L. W., Burney, G. A., King, C. M., Separation of ${ }^{241}$ Am from Calcium and Lead using Masking and Multiple Oxalate Precipitation Techniques, DP-1765, Savannah River Site, August 1988.

45. Bibler, N. E., Oxidation of $\mathrm{H}_{2} \mathrm{C}_{2} \mathrm{O}_{4}$ by $\mathrm{HNO}_{3}-\mathrm{Mn}$ in F-Canyon, DPST-79-278, Savannah River Site, March 1979.

46. Patello, G. K., Russell, R. L., Golcar, G. R., Smith, H. G., Smith, G. L., Elliott, M. L., Processing Simulated Oxalated High Level Waste Through a Vitrification Feed Preparation Flowsheet, Environmental Issues and Waste Management Technologies in the Ceramic and Nuclear Industries IV, Ceramic Transactions Volume 93, J. C., Marra and G. T. Chandler, eds., American Ceramic Society,1999, Westerville, Ohio.

47. Anson, F. C., Schultz, F. A., Effect of Adsorption and Electrode Oxidation of the Oxidation of Oxalic Acid at Platinum Electrodes, Anal. Chem., 35, (1963), 1114-1116.

48. Chollier-Brym, M. J., Epron, F., Lamy-Pitara, E., Barbier, J., Catalytic and Electrocatalytic Oxidation of Oxalic Acid in Aqueous Solutions of Different Compositions, J. Electroanal. Chem., 474, (1999), 147-154.

49. De Lima, R. B., Paganin, V., Iwasita, T., Vielstich, W., On the Electrocatalysis of Ethylene Glycol Oxidation, Electrochim. Acta, 49, (2003), 85-91. 
50. Berna, A., Rodes, A., Feliu, J. M., Oxalic Acid Adsorption and Oxidation at Platinum Single Crystal Electrodes, J. Electroanal. Chem., 563, (2004), 49-62.

51. Scialdone, O., Randazzo, S., Galia, A., Filardo, G., Electrochemical Oxidation of Organics at Metal Oxide Electrodes: The Incineration of Oxalic Acid at IrO2-Ta2O5 (DSA-O2) Anode, Electrochim. Acta, (2008), in press.

52. Ivandini, T. A., Rao, T. N., Fujishima, A., Einaga, Y., Electrochemical Oxidation of Oxalic Acid at Highly Boron-Doped Diamond Electrodes, Anal. Chem., 78, (2006), 3467-3471.

53. Canizares, P., Paz, R., Saez, C., Rodrigo, M. A., Electrochemical Oxidation of Alcohols and Carboxylic Acids with Diamond Anodes: A Comparison with Other Advanced Oxidation Processes, Electrochim. Acta, 53, (2008), 2144-2153.

54. Panizza, M., Cerisola, G., Application of Diamond Electrodes to Electrochemical Processes, Electrochim. Acta, 51, (2005), 191-199.

55. Onder, E., Koparal, A. S., Ogutveren, U. B., Electrochemical Treatment of Aqueous Oxalic Acid Solution by Using Solid Polymer Electrolyte (SPE) Reactor, Chem. Eng. J, (2008), in press.

56. Yang, L., Ray, M. B., Yu, L. E., Photooxidation of Dicarboxylic acids-Part II: Kinetics, Intermediates, and Field Observations, Atmospheric Environment, 42, (2008), 868-880.

57. Wang, F. T., Lum, B. Y., Photolytic Destruction of Oxalate in Aqueous Mixed Waste, Proceedings of the Third Biennial Mixed Waste Symposium, Baltimore, MD, August 7-11, 1995.

58. Bertholdt, H. E. to Framatome ANP GmbH (Erlangen, DE), U. S. Patent 6,444,276 (September 3, 2002).

59. Rosenfeldt, E. J., Linden, K. G., Canonica, S., von Gunten, U., Comparison of the Efficiency of $\mathrm{OH}$ Radical Formation during Ozonation and the Advanced Oxidation Processes $\mathrm{O}_{3} / \mathrm{H}_{2} \mathrm{O}_{2}$ and $\mathrm{UV} / \mathrm{H}_{2} \mathrm{O}_{2}$, Water Research, 40, (2006), 3695-3704.

60. Von Gunten, U., Ozonation of Drinking Water: Part I. Oxidation Kinetics and Product Formation, Water Research, 37, (2003), 1443-1467.

61. Quici, N., Morgada, M. E., Piperata, G., Babay, P., Gettar, R. T., Litter, M. I., Oxalic Acid Destruction at High Concentrations by Combined Heterogeneous Photocatalysis and Photo-Fenton Processes, Catalysis Today, 101, (2005), 253-260.

62. Legrini, O., Oliveros, E., Braun, A. M., Photochemical Processes for Water Treatment, Chem. Rev., 93 (1993) 671-698. 
63. Kosanic, M. M., Photocatalytic Degradation of Oxalic Acid over $\mathrm{TiO}_{2}$ Power, J. Photochem. PhotoBio. A: Chem, 119 (1998) 119-122.

64. He, Z., Xu, X., Song, S., Xie, L., Tu, J., Chen, J., Yan, B., A Visible Light-Driven Titanium Dioxide Photocatalyst Co-doped with Lanthanum and Iodine: An Application in the Degradation of Oxalic Acid, J. Phys. Chem. C, 112 (2008) 16431-16437.

65. Mason, J. B., Wolf, K., Ryan, K., Roesener, S., Cowen, M., Schmoker, D., Bacala, P., Landman, B., Steam Reforming Application for Treatment of DOE Sodium Bearing Tank Wastes at Idaho National Laboratory for Idaho Cleanup Project, Proceedings of the Waste Management 2006 Conference, Tucson, AZ, February, 2006.

66. Shende, R. V., Mahajani, V. V., Kinetics of Wet Air Oxidation of Glyoxalic Acid and Oxalic Acid, Ind. Eng. Chem. Res., 33 (1994), 3125-3130.

67. Okawa, K., Suzuki, K., Takeshita, T., Nakano, K., Degradation of Chemical Substances Using Wet Peroxide Oxidation Under Mild Conditions, J. Hazardous Materials, B127 (2005), 68-72.

68. Yao, R., Sun, M., Wang, C., Deng, S., Degradation of Phenolic Compounds with Hydrogen Peroxide Catalyzed by Enzyme from Serratia Marcescens, Water Research, 40 (2006), 3091-3098.

69. Sjode, A., Winestrand, S., Nilvebrant, N., Jonsson, L. J., Enzyme-Based Control of Oxalic Acid in the Pulp and Paper Industry, Enzyme and Microbial Technology, 43 (2008), 78-83.

70. Shin, W., Yiacoumi, S., Tsouris, C., Dai, S., A Pulseless Corona-Discharge Process for the Oxidation of organic Compounds in Water, Ind. Eng. Chem. Res., 39 (2000), 44084414.

71. Dukkanci, M., Gunduz, G., Ultrasonic Degradation of Oxalic Acid in Aqueous Solutions, Ultrasonic Sonochemistry, 13 (2006), 517-522.

72. Joseph, C. G., Puma, G. L., Bono, A., Krishnaiah, D., Sonophotocatalysis in Advanced Oxidation Process: A Short Review, Ultrasonic Sonochemistry, 16 (2009), 583-589.

73. Harada, H., Tanaka, H., Sonophotocatalysis of Oxalic Acid Solution, Ultrasonics, 44 (2006), e385-e388.

74. Chen, L., Chamberlain, D. B., Conner, C., and Vandegrift, G. F., A Survey of Decontamination Processes Applicable to DOE Nuclear Facilities, ANL-97/17, Argonne National Laboratory, May 1997. 
75. Shields, K. J., Chemical Cleaning of Fossil Power Station Steam Generators; Past, Present, and Future, $14^{\text {th }}$ International Conference on the Properties of Water and Steam, Kyoto, Japan, 475-483, August 19 - September 3, 2004.

76. Wang, Y. and. Stone, A. T., Reaction of $M n^{I I I, I V}$ (Hydr)oxides with Oxalic Acid, Glyoxylic Acid, Phosphonoformic Acid, and Structurally Related Organic Compounds, Geochimica et Cosmochimica Acta, 70, (2006), 4477-4490.

77. Powell, B. A., L. Rao, K. L. Nash, and L. Martin, Behavior of Uranium(VI) During HEDPA Leaching for Aluminum Dissolution in Tank Waste Sludges, Actinides 2005, Basic Science, Applications, and Technology, Materials Research Society (2005).

78. Al-Hobaib, A. S., Al-Dhayan, D. M., Al-Sulaiman, K. M., Al-Suhybani, A. A., Radium Desorption, Manganese and Iron Dissolution from Sand Filters of a Conventional Ground Water Treatment Plant under Reductive Conditions, Journal of Radioanalytical and Nuclear Chemistry, 269, (2006), 51-62.

79. Edna et al. to Kabushiki Kaisha Toshiba (Tokyo, JP), U. S. Patent 7,087,120 (August 8, 2006).

80. Hamm, B. A., Eibling, R. E., Fowler, J. R., Demonstration of In-Tank Sludge Processing Part I. Aluminum Dissolution, Sludge Washing and Settling Results, DPST83-668, Rev. 0, Savannah River Site, July 1983.

81. Lumetta, G. J., Rapko, B. M., Liu, J., Temer, D. J., Hunt, R. D., Washing and Caustic Leaching of Hanford Tank Sludge: Results of FY 1998 Studies, PNNL-12025, Pacific Northwest National Laboratory, December 1998.

82. Lumetta, G. J., Darnell, L. P, Garza, P. A., Greenwood, L. R., Oliver, B. M., Rinehart, D. E., Sanders, D. R., Soderquist, C. Z., Trang-Le, T., Urie, M. W., Wagner, J. J., Caustic Leaching of Hanford Tank T-110 Sludge, PNNL-13956, Pacific Northwest National Laboratory, July 2002.

83. Hay, M. S., Pareizs, J. M., Bannochie, C. J., Stone, M. E., Click, D. R., McCabe, D. J., Characterization and Aluminum Dissolution Demonstration with a 3 Liter Tank $51 \mathrm{H}$ Sample, WSRC-STI-2007-00697, Rev. 0, Savannah River Site, February 2008.

84. Hay, M. S., Pareizs, J. M., Bannochie, C. J., Stone, M. E., Click, D. R., McCabe, D. J., Characterization and Aluminum Dissolution Demonstration with a 3 Liter Tank 51H Sample, WSRC-STI-2007-00697, Rev. 0, Savannah River Site, February 2008.

85. Hay, M. S., Preliminary Results of the Tank $12 \mathrm{H}$ Aluminum Dissolution Demonstration, SRNL-L3100-2008-00127, Rev. 0, Savannah River Site, November 2008. 
86. Hay, M. S., Adu-Wusu, K., McCabe, D. J., Determination of the Fraction of Gibbsite and Boehmite Forms of Aluminum in Tank 51H Sludge, WSRC-STI-2008-00366, Rev. 0, Savannah River Site, August 2008.

87. Spencer, B. B., Collins, J. L., Hunt, R. D., Caustic Leaching of SRS Tank 12 H Sludge With and Without Chelating Agents, ORNL/TM-2002/195, Oak Ridge National Laboratory, April 2003.

88. Zhou, B., J. Z. Li, C. H. He, and S. Y. Qin, EDTA-type Polymer Based on Diazacrown Ether as the Solubilizer of Barium Sulfate to Water, Chinese Chemical Letters, 16, 1, p. 27-30, 2005.

89. Woodgate, P. D., G. M. Horner, N. P. Maynard, and C. E. F. Rickard, Interphase Transmetallation of Copper(II) by Spiroboronates, Journal of Organometallic Chemistry, 590, 1, 52-62, 15 November 1999, Elsevier.

90. Moyer, B. A. and R. P. Singh, Fundamentals and Applications of Anion Separations, p. 107, American Chemical Society Meeting, ISBN:0306479117, Springer, 2004. Chapter/Paper Title: “The Problem with Anions in the DOE Complex” by G. J. Lumetta.

91. Ketusky, E. T., Determination of an Alternative Technology for HLW Tank Chemical Cleaning, WSRC-STI-2007-00587, Savannah River Site, October 2007.

92. Wille, H., Bertholdt, H., Roumiguiere, F., Chemical Decontamination with the CORDUV Process: Principle and Field Experience, Proceedings of the $4^{\text {th }}$ Regional Meeting, Nuclear Energy in Central Europe, Bled, Slovenia, September 7-10, 1997.

93. Davis, N. R., E. T. Ketusky, R. H. Spires, R. E. Beatty, S. D. Jones, J. F. Remark, and P. A. Wotjaszek, Enhanced Chemical Cleaning: A New Process for Chemically Cleaning Savannah River Waste Tanks, LWO-LWE-2008-00009, Rev. 0, Savannah River Site, February 2008.

94. Zhang, Y., Kallay, N., Matijevic, E., Interactions of Metal Hydrous Oxides with Chelating Agents. 7. Hematite-Oxalic Acid and -Citric Acid Systems, Langmuir, 1, (1985), 201-206.

95. Blesa, M. A., Marinovich, H. A., Baumgartner, E. C., Maroto, A. J., Mechanism of Dissolution of Magnetite by Oxalic Acid-Ferrous Ion Solutions, Inorg. Chem, 26, (1987), 3713-3717.

96. Suter, D., Banwart, S., Stumm, W., Dissolution of Hydrous Iron(III) Oxides by Reductive Mechanisms, Langmuir, 7, (1991), 809-813. 
97. Rodenas, L. A., Blesa, M. A., Morando, P. J., Reactivity of Metal Oxides: Thermal and Photochemical Dissolution of $\mathrm{MO}$ and $\mathrm{MFe}_{2} \mathrm{O}_{4}(\mathrm{M}=\mathrm{Ni}, \mathrm{Co}, \mathrm{Zn})$, J. Solid State Chem., 181, (2008), 2350-2358.

98. Torres, R. M., Blesa, M. A., Matijevic, E., Interactions of Metal Hydrous Oxides with Chelating Agents. VIII. Dissolution of Hematite, J. Colloid Interface Sci., 131, (1989), 567-579.

99. Torres, R. M., Blesa, M. A., Matijevic, E., Interactions of Metal Hydrous Oxides with Chelating Agents. IX. Reductive Dissolution of Hematite and Magnetite by Aminocarboxylic Acids, J. Colloid Interface Sci., 134, (1990), 475-485.

100. Baumgartner, E. C., Blesa, M. A., Marinovich, H. A., Maroto, A. J., Heterogeneous Electron Transfer as a Pathway in the Dissolution of Magnetite in Oxalic Acid Solutions, Inorg. Chem, 22, (1983), 2224-2226.

101. Christodoulou E, Panias, D., Paspaliaris, I., Calculated Solubility of Trivalent Iron and Aluminum in Oxalic Acid Solutions at $25^{\circ} \mathrm{C}$, Canadian Metallurgical Quarterly, 40, (2001), 421-432.

102. Panias, D., Taxiarchou, M., Paspaliaris, I., Kontopoulos, A., Mechanisms of the Dissolution of Iron Oxides in aqueous Oxalic Acid Solutions, Hydrometallurgy, 42, (1996), 257-265.

103. Herman, C. C., Click, D. R., Fondeur, F. F., Stone, M. E., Initial Results for SRNL Characterization and Settling Tests of Tank 51-Sludge Batch 4, SRNL-ITS-200500272, Savannah River Site, December 2005.

104. Martino, C. J., Evaluation of Alternative Chemical Cleaning and Enhanced Chemical Cleaning Methods, SRNL-L3100-2009-00118, Savannah River Site, June 2009. 